\title{
Articles
}

\section{Spanish Thin Capitalisation in Light of the Non-Discrimination Principle: its Compatibility with Double Tax Treaties and EC Law'}

Dr. José M. Calderón Carrero, University of La Coruña, Spain

\section{Introduction}

This article aims to analyse both the current as well as the projected Spanish regulation on corporation thin capitalisation. It is essentially concerned with the compatibility of said regulation with the Double Taxation Conventions (DTCs) that follow the OECD Model Convention (MC OECD). It will also deal with the regulation's compatibility with the nondiscrimination principle concerning nationality as approved at Community level.

It is therefore necessary to introduce the problems that arise when dealing with the thin capitalisation norm. Failure to examine the framework and basic coordinates related to this phenomenon would result in the study lacking any basis and, as such, the study would probably be erroneous. Therefore, before examining the compatibility of the Spanish anti-thin capitalisation norm with the DTCs and Community law, a synthetic examination of the doctrine of the OECD Fiscal Committee on thin capitalisation must be carried out. The origin and problems for the parties involved, the consequences of enforcing the Spanish measure, the overlapping with the DTCs, with EC law (Directive 90/435) and the application of the Convention 90/436 will all be looked at in turn.

The aim of this article is not so much to provide a description of the Spanish anti-thin capitalisation arrangement, but rather to carry out a global analysis of the phenomenon, the Spanish Tax Administration position in connection to it, outlining thoughts on the current thin capitalisation norms in relation to existing principles on international taxation (OECD doctrine), EC law and jurisprudence. Furthermore, an introduction to a rethinking of thin capitalisation (in general) in light of Community requirements will be attempted.

\section{Approximation to the Problem of Thin Capitalisation}

The problem of thin capitalisation ${ }^{2}$ is closely linked to the different forms of financing by corporations which are of a similar group or are under common control.

1 The author gratefully acknowledges the assistance of the following colleagues: J. Arnau Sierra (Lawyer of Inditex/ Zara), A. Baena Aguilar (University of Barcelona), M.A. Caamano Anido (University of La Coruña), R. Fuster Tozer (Lawyer of Uría \& Menéndez, Madrid) and F.A. Garcia Prats (University of Valencia) for their comments on the draft of this article. Please note: the new Spanish Corporation Income Tax Law is in force with effect from 1 January 1996. The new Corporation Income Tax Law (Law 43/95, 27 December) replaces Law 61/78, 27 December. However, there are two main objectives when discussing Law 61/78 in this article. On the one hand, it is useful insofar as the new regulation is based upon and follows on from said law; whilst on the other hand, it shows how a solution to some of the problems to be found in Law 61/78 have been attempted (notably its incompatibility with the tax treaties).

2 In relation to Spanish thin capitalisation see the following studies: C. Palao Taboada, 'La subcapitalización y los Convenios de doble imposición', Revista de Estudios Financieros, no. 137-138, p. 77; A. Rey Arnaiz, 'La subcapitalización', GF, (Yearbook 1993), vol. 1, p. 491 et seq.; V. Gonzalez Poveda, 'La subcapitalización: un problema nuevo del Impuesto sobre Sociedades', Impuestos, vol. II, 1992, p. 82 et seq.; G. Gutierrez Sanchez, Regife Longedo, Tomas Hernandez, 'Aspectos internacionales de la evasión y el fraude fiscal', Impuestos, no. 22, 1993, p. 12 et seq., p. 16 et seq.; B. Jackson, 'Thin Capitalization', European Taxation, 1990, p. 319 et seq.; J.D.B. Oliver, 'Interest, Dividend and the Elimination of Double Taxation (arts. 10, 11 and 23)', Intertax, 1992/12, p. 680 et seq.; J.L. De Juan Penalosa, 'Modelo OCDE/92', Impuestos, no. 15-16, 1993, p. 18 et seq.; G. Gutierrez De Pablo, 'Diversos aspectos de la planificación fiscal internacional y el uso de los paraísos fiscales. Análisis de algunas medidas de prevención', Impuestos, no. 10/95, pp. 25-26; F. Rey Y Collado, 'Aspectos fiscales de la subcapitalización de sociedades: Derecho Comparado', Impuestos, vol. 1, 1993, p. 77 et seq.; E. Sanz Gadea, Impuesto sobre Sociedades 
It is usual to make a distinction between financing through stockholder's equity (contributions of the associates or shareholders) and by debt resources (loans). These two options have different profiles, as much from a commercial point of view as from a fiscal law point of view. This can be a determinant when 'designing' or planning the financial structure of the groups.

On the one hand, the shareholders that share in the capital of the corporation have the right to profit-sharing should the company obtain positive results. The way 'to remunerate' the investment of the shareholder is through the distribution of dividends. As is known, dividends are generally subject to economic double taxation when their recipient is another company. ${ }^{3}$ Nevertheless, it is necessary to emphasise that it has been common recently for the effects of the aforementioned phenomenon to be eliminated or eased through either internal ${ }^{4}$ or international ${ }^{5}$ procedures (economic double taxation relief).

Generally, when dealing with debt financing, the lender has the right to fixed remuneration, independent of the results of the borrowing company. The lender also has the right to recover the loan in the agreed time limit. However, on occasions the lender may also share in the entrepreneurial borrowing risk. This occurs, for example, in cases of share loans, ${ }^{6}$ when the convertibility of the credit in share capital is introduced, or when clauses of subordination of the lender in the creditor's marshalling are introduced. In these cases we are dealing with so-called hybrid financing. ${ }^{7}$

Fiscal treatment of debt financing is generally more advantageous for groups than by resorting to financing through stockholders' equity. We must bear in mind that not only is the interest paid to the lender not subject economic double taxation, ${ }^{8}$ but it also constitutes a deductible operating expense on the taxable income of the borrower. ${ }^{9}$ At the same time, the interest in the international taxation arena is usually subject to lower rates of tax than that applicable to dividends. ${ }^{10}$ In this situation, the lender (and the group) obtain a greater net

cont.

(Comentario y Casos Prácticos), vol. 1 (CEF, Madrid, 1991), p. 382 et seq.; A. Gota Losada, Tratado del Impuesto de Sociedades, vol. 2 (Extecom, Madrid, 1988), p. 280 et seq., p. 398 et seq.; L. Fernandez Briones, Criterios para diseñar un régimen fiscal que evite el uso de sociedades domiciliadas en paraisos fiscales para reducir los impuestos españoles (Monograph no. 49, Madrid, IEF, 1987), p. 40 et seq.; J.M. Farré Espanol, La Doble Imposición. Modelo OECD 1992 (Einia, Barcelona, 1994), p. 148 et seq.

3 On the concept and profiles of economic double taxation on dividends see J.R. Ruiz Garcia, La Deducción por Dividendos en el sistema tributario español (Civitas, Madrid, 1991), pp. 29-39; R. Falcon Y Tella, Análisis de la transparencia tributaria (IEF, Madrid, 1984), p. 199; Melero Guazza, 'La doble imposición en el marco de la CEE. Especial referencia a los dividendos' in Constitución y Normas Tributarias (Aranzadi, Pamplona, 1991), p. 515 et seq.; R. Cross, The Double Imposition des Dividendes (Economie Contemporaine, Paris, 1991), pp. 1-12; Report Carter, vol. 3 (IEF, Madrid, 1975), p. 22; A. Barrado Muñoz, 'La deducción por doble imposición interna de los dividendos', RDFHP, no. 235,1995 , p. 101 et seq

4 According to art. 24.5 (in the text given by art. 9 of Law 42/94, 30 December) the deduction of the underlying tax to the dividends is admitted as long as the recipient resident corporation exhibits a direct participation of at least 25 per cent of the capital of his subsidiary non-resident.

5 Between the DTCs ratified by Spain in which the effects of economic double taxation on dividends are eliminated, you can see the tax treaties with Austria, Australia, Argentina, France, the United Kingdom, Belgium, Canada, Denmark, Finland, Japan, Romania, Sweden, Switzerland, India and Ireland. Also, Community Directive 90/435, of 20 July 1990, of applicable common fiscal rules to parent company/subsidiary (implemented to our Law by Law $29 /$ 91, of 16 December) has suppressed the economic double taxation that falls on the profit distributions between the parent company and resident subsidiaries in different Member States of the European Union.

6 In relation to the nature of the interest derived from participative loans J.R. Ruiz Garcia, La Deducción por Dividendos en el Sistema Tributario Español, op. cit. n. 3 at p. 44 et seq., has underlined its 'uncertain character ... to present common notes to the dividend and to the interest' whose adherence to one or other of the concepts may be problematic, especially on hidden fraudulent operations.

7 See E. Sanz Gadea, Impuestos sobre Sociedades (Comentarios y Casos Prácticos), vol. 1, op. cit. n. 2 at p. 382 ; Rey y Collado 'Aspectos fiscales de la subacapitalización de sociedades: Derecho Comparado', op. cit. n. 2 at pp. 78-79. In this sense, some authors have shown the negative influence that economic double taxation exerts over the corporation's financing system. Particularly, they insist on the discriminatory effect that double taxation has on capital financing in contrast to debt resources financing, on the basis that this last finance formula offers a greater economic benefit because it enjoys better fiscal treatment (i.e. exemptions and no double taxation). See J. Van Hoorn, 'International Tax Aspects of Corporate Financing', European Taxation, no. 10, 1966, p. 228 et seq.; A. Jacquemin \& C. Parmentier, La double Imposition économique des bénéfices et les mésures d'allegement (Vander, Louvain, 1968), pp. 28-29.

9 See art. 13.1 Law 61/78, 27 December, of Corporation Tax Law (hereafter, LIS).

10 The Model Convention of the OECD (version 1992) (hereafter, MC OECD) to avoid the international double taxation on revenue and capital, establishes a tax rate of 15 per cent and 5 per cent (parent company/subsidiary, 25 per cent participation in capital) for dividends and 10 per cent for the interest (see arts. 10.2 and 11.2 MC OECD). The MC US (Treasury Model, version 1981) sanctions the same taxation for dividends, while the interest can only be submitted to taxation by the resident of the effective beneficiary of the same (art. 11.1 MC US). Also, by virtue of art. 23, Three, and 1) LIS, the interest will be exempt in Spain when it corresponds to legal persons or non-resident entities that may have their fiscal residence in other countries of the European Union, provided that they do not operate a permanent establishment in Spain. The mentioned exemption is present in art. 46.1 a) of the Project of (new) Corporation Income Tax Law (Parliament Bulletin (hereafter, BOF) nos. 106-13, 6 October).

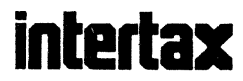


benefit from the operation. Furthermore, we must point out the tax saving which arises as a result of contributing to stockholder's equity (contributions to the corporation) - 1 per cent of the transfer tax (ITP) in its corporate operations modality. ${ }^{11}$

Without a doubt it is in the international operations framework where the greatest advantage from fiscal financial planning of the group through 'debt resources' can be obtained. This is especially so when the lender resides in a Tax Haven or has a privileged statute. However, at a national level, benefits can be obtained by following this formula when the intention is to place part of the profit in those corporations of the group which are subject to a lower tax rate, or those which carry losses or have credits that offset their tax. ${ }^{12}$

Having said this, one should be careful not to consider thin capitalisation as strictly a problem of tax evasion. The reason for this is that in the majority of cases where it occurs the lender is a resident of a country with similar tax rates to those of the source State. Therefore, the tax saving is, in general, so small that it would not carry sufficient weight to influence or determine the financial policy of the group. However, thin capitalisation does not constitute a hypothetical case of tax evasion, nor does the relevance given to it by the States involved. It is true however, that even where thin capitalisation is not carried out for the purpose of tax savings there is a violation of an important international principle on the distribution of the tax power between States, i.e. the arm's length principle. As we know, through the pursuit of this principle each State has the right to tax any profits which the taxpayers may have obtained in their own country, had they been an independent person in a full competition situation in the market. In this context, the operability of this postulate, as concerns thin capitalisation, allows the borrower State of residence to recover tax revenue that it would have obtained had the parties been independent. The anti-thin capitalisation rules are not so much concerned with the struggle against tax evasion but with the enforcement of a tax power distribution principle, the breaching of which results in a loss of tax revenue, as occurs with transfer pricing. ${ }^{13}$

As such, thin capitalisation is derived from considering that when, as a result of the relationship between two companies, the subsidiary heavily structures its financial policy on the debt resources route facilitated by the group of which it forms part. The operation is considered to be a contribution to hidden equity capitalisation by the parent company. This is usually because of the tax advantages obtained from financing by debt resources.

It is in this context that thin capitalisation must be understood. It is considered to occur 'when the proportion between the volume of debt/equity resources which come directly or indirectly from the corporations within the group is greater than a proportion considered normal in free competition situations. Thin capitalisation implies a financial structure in which the debt resources from linked corporations make up the largest section of financing, normally with the objective of reducing the taxable profit of the subsidiary. ${ }^{14}$

It must also be pointed out that thin capitalisation constitutes a different problem to that of inter-group loans which result in either excessive interest, very low interest or no remuneration. Certainly, both phenomena have common characteristics, insofar as they exist as a result of planning by persons linked under common control and that they also constitute a transgression of the free competition principle in the market (arm's length principle). In the case of thin capitalisation however, the existence (or non-existence) of transfer pricing between the parties involved has no relevance. However, in the case of transfer pricing adjustments the presence of inter-group loans with either excessive interest, very low interest or no remuneration, constitutes the essence of the problem. ${ }^{15}$

Once the negative effects of thin capitalisation on tax collection were detected, many countries, including Spain, reacted by drawing up various measures in order to limit the

11 See art. 26 of the RD. 1/93, 24 September, of Recasted Text of the transfer tax (ITPAJD).

12 See Rey y Collado, 'Aspectos fiscales de la subcapitalización de sociedades: Derecho Comparado', op. cit. n. 2 at pp. 78-79.

13 In a similar sense, see Ph. Jans, Les transferts indirects de bénéfices entre sociétés interdépendantes (Droit Fiscal Belge et Comparé. Perspectives internationales et communautaires europpéennes), (Bruylant, Bruxelles, 1976), p. 35 et seq.

14 Rey y Collado, 'Aspectos fiscales de la subcapitalización de sociedades: Derecho Comparado', op. cit. n. 2 at p. 79.

15 In the same sense see A. Gota Losada, Tratado del Impuesto de Sociedades, vol. 2, op. cit. n. 2 at p. 398 et seq.; E. Sanz Gadea, Impuesto de Sociedades (Comentarios y Casos Prácticos), vol. 1, op. cit. n. 2 at p. 382; Rey y Collado, 'Aspectos fiscales de la subacapitalización de sociedades: Derecho Comparado', op. cit. n. 2 at pp. 79-80. Some procedures, such as arts. 9.1 and 11.6 of the MC OECD, could be employed to remedy these practices, adjusting the profits of the involved parties through the arm's length principle. See the OECD Report 'The Sous-Capitalisation' (in Questions of Fiscalité Internationale, no. 3, Paris, 1987, para. 22). The same conclusion is derived from the commentaries of the Fiscal Committee on arts. 9.1 and 11.6 MC OECD 1992. Nevertheless, determined substantive differences can be found in the application of these two precepts. See J.D.B. Oliver, 'Interest, Dividend and the Elimination of Double Taxation', Intertax, 1992/12, p. 681; K. Vogel, Double Taxation Conventions (Kluwer, Deventer, 1990), p. 678 et seq., P. Baker, Double Taxation Conventions and International Tax Law (Sweet \& Maxwell, London, 1994), p. 254 et seq.; J.M. Farré Español, Doble Imposición. Modelo 1992 (Einia, Barcelona, 1994), pp. 219221 . 
distortions which were resulted from this financial practice and, above all, to avoid the loss of tax income.

The OECD Report 'La Sous-Capitalisation'16 highlights how this phenomenon can be counteracted by subjective and objective methods.

The subjective methods ${ }^{17}$ operate by way of an analysis of all the circumstances present in a concrete case. This is to determine if in arm's length conditions, the borrower corporation would have been able to obtain the representative loans at the existing indebtedness level from an independent company. It must also be considered whether the lender corporation, being a company linked to the borrower, would have demanded a share of the profits of said company. Other tests proposed by the OECD to verify this situation come from contrasting the following data: the ratio of indebtedness/capital before the operation; the fact that the loan is destined to cover losses; its convertibility into shares; the link of the interest to the corporation profits (share loans) and its subordination to other creditors. ${ }^{18}$

In relation to the objective methods,${ }^{19}$ the OECD has underlined the application of the system of the ratio or fixed coefficient of debt/equity resources above which the loan would be treated as a contribution to capital. Nevertheless, the OECD Committee of Fiscal Matters has specified that this technique is acceptable and compatible with the MC OECD, insofar as the implicated corporation 'is permitted the option of demonstrating that the debt/equity ratio is a market coefficient (perhaps, for example, by demonstrating that it corresponds to the customary indebtedness of companies in the same activity in the country) ${ }^{20}$ At the same time, the OECD has specified the importance of the fact that 'the fixed ratios adopted by the fiscal authority must be flexible enough to minimise the number of contributors that are obliged to demonstrate that their ratio is adjusted to the arm's length principle'.

Nevertheless, it is necessary to specify that these affirmations of the OECD Fiscal Committee have not received the necessary support for their full enforcement in the DTCs that follow the MC OECD. The lack of international consensus on this point has resulted in these principles appearing quite diluted in the commentaries introduced by the OECD Fiscal Committee in relation to thin capitalisation in arts. 9.1, 10.3, 11.6, 23 and 25 of the MC OECD. The commentaries on art. 9.1 (number $2 \mathrm{a}$ and c) point out the limiting character of this rule, 'the application of rules designed to deal with thin capitalisation should not normally have the effect of increasing the taxable profits of the relevant domestic enterprise further than the arm's length profit'. It also states that, 'this principle should be followed in the application of the existing tax treaties'. Paragraph 4 (in fine) of the commentaries of art. 9.1 warns of the impossibility of carrying out these adjustments when the contracting States establish reversal of the burden of proof procedures, or other rigorous presumptions that could lead to taxation being inconsistent with the arm's length principle. In this sense, a systematic reading of the doctrine (put in the commentaries to the MC OECD and in the thin capitalisation report) shows (the need for) a certain flexibility and subjectivity in the objective methods for the sake of guaranteeing their true suitability with the arm's length principle, as the defence of the taxpayer (contradiction principle).

The consequences of applying a thin capitalisation procedure affect the two parties involved in the loan, by trying to eliminate substantially the loss of tax initially originated through the corresponding fiscal treatment of the non-arm's length situation to its 'real nature'. Therefore, the interest paid in excess is now considered dividends. ${ }^{21}$ Consequently, the paying corporation will not (usually) be able to deduct the 'dividends' from its taxable income and, the lender, the recipient of the dividends, will be charged at source at the rate of tax applicable to the dividends. ${ }^{22}$

16 OECD, 'La Sous-Capitalisation' in Questions de Fiscalité Internationale, no. 2, op. cit. n. 15 at para. 25.

17 OECD, 'La Sous-Capitalisation' in Questions de Fiscalité Internationale, no. 2, op. cit. n. 15 at para. 25 i). Also, it is necessary to emphasise that the principles exposed by the OECD on this point of the report have carried a greater international consensus and legal efficiency and have been included in no. 25 of the commentaries of the Fiscal Committee (art. 10.3 MC OECD 1992).

is It is important to note that these last three criteria constitute an expression of the participation of the lender in the risks of the borrower company, inasmuch as that constitutes a financial hybrid instrument, whose interest, as has already been underlined, lies midway between this type of revenue and dividends.

19) OECD, 'La Sous-Capitalisation', op. cit. n. 15 at para. 25 ii).

20) Cf. no. 79 of the report 'La Sous-Capitalisation', op. cit. n. 15 at and the OECD Committee of Fiscal Affairs in the Report of 1979 'Prices of Transfer and Multinational Companies' (Spanish version by J.M. De la Villa Gil, IEF, Madrid, 1986), paras. 179-191.

21 See OECD 'La Sous-Capitalisation', op. cit. n. 15 at paras. 26 et seq., and no. 35 of the commentaries on art. 11.6 and nos. 67-69 of commentaries on art. 23 MC OECD 1992.

22 The non-resident without permanent establishment who is taxed at source on interest now the object of reassessment as dividends, would only be taxed, eventually, on the difference between the tax satisfied in the past and the tax corresponding to the 'dividends'. It seems logical to impose no sanctions to demand delay interest when it is not a fraudulent case insofar as this circumstance is excluded by the Spanish Tax Administration on transfer prices 
It should be mentioned that the fiscal treatment of the excess of interest in 'dividends' is the basis of the thin capitalisation rule, i.e. the act of reassessment is subject to additional limitations in the framework of the DTCs that follow the MC OECD. The OECD Committee has established in the commentaries on art. $10.3^{23}$ that 'article 10 deals not only with dividends as such but also with interest on loans, insofar as the lender shares the risks run by the company, i.e. when repayment depends largely on the success or otherwise of the enterprise's business. Articles 10 and 11 therefore do not prevent the treatment of this type of interest as dividends under the national rules on thin capitalisation applied in the borrower's country.' This premiss for the application of thin capitalisation rules in the framework of DTCs is reiterated in the commentaries on art. $23 \mathrm{~A}$ and B MC OECD $1992^{24}$ where it states "in so-called thin capitalisation situations, the Model Convention allows the State of the borrower company, under certain conditions, to treat an interest payment as a distribution of dividends in accordance with its domestic legislation; the essential condition is that the contributor of the loan should effectively share the risks run by the borrower company'.

Also, in order to avoid the tax chaos which results from asymmetrical fiscal revenue (interest/ dividend) calculations by the State of the source and that of the residence of the recipient, the OECD Committee of Fiscal Matters, ${ }^{25}$ at least to the effects of the MC OECD 1992, establishes, in certain conditions ${ }^{26}$ the principle of the binding assessment given by the thin capitalisation law of the contracting State, the borrower's residence. This is the same as saying that the State of residence of the recipient of the "dividend" (excessive reassessed interest) will treat the said emolument as if it were an authentic dividend. This implies acceptance of the application of the distribution procedures of the tax power stipulated in the DTC for this type of revenue, as well as all the tax Acts derived which are complementary to the assessment. In particular, it should accept the exaction at source of a withholding tax (if there isn't a permanent establishment in the source country) at the tax rate applicable to dividends and eliminate both international and economic double taxation of these revenues in the way stipulated in the treaty.

Finally, in reference to the application of national thin capitalisation arrangements in the scope of DTCs that follow faithfully the MC OECD, the OECD Committee of Fiscal Matters has approved the inapplicability of these arrangements in the mentioned framework when they produce results contrary to the non-discrimination principle taken up in art. 24 of the Model Convention. ${ }^{27}$ This principle will be violated when the thin capitalisation procedure runs contrary to arts. 9.1 and 11.6 and only when applied to the non-resident lenders of the contracting State of that regulation.

Therefore, it is easy to see how the application of the national thin capitalisation rules introduces certain neutrality in the finance strategy of the corporate groups, insofar as many of the advantages of the listing toward the debt resources route are cancelled. Nevertheless, the reason for this regulation does not come from the achievement of fiscal neutrality in the corporation's financing, but from avoiding the tax loss initially sustained by the borrower's State of residence, something which is achieved when adjusting the taxation of the involved parties to the arm's length principle.

It should not be forgotten that the operability of these national thin capitalisation procedures cannot be carried out in a discriminatory way in the framework of the DTCs that follow the MC OECD. As has been seen, these procedures are subject to conditions which, if not met, cannot be applied in the area of the international fiscal relations covered by these treaties.

\section{Substantive Profiles of the Spanish Anti-thin Capitalisation Regulation}

The Spanish regulation with reference to the thin capitalisation arrangement was introduced through the Fifth Additional Arrangement of Law 18/91, on 6 June by the IRPF. This law modified art. 16, law 61/1978 of 27 December, of the Corporation Tax Law (hereafter, LIS) adding to the content of para. 9 of said law the following terms:

cont.

(RR.TEAC of 9 March 1993 (JT 93, Ar.597) and of 4 May 1994 (JT 94, Ar.822)). See F.J. Magraner Moreno and F.J. Quiles Bodi, 'La aplicación del principio de culpabilidad en el Derecho Tributario sancionador', JT, no. 60/1995, pp. 33-34. See also the recent considerations expressed in this field by the OECD Fiscal Committee on the Report 'Transfer Pricing Guidelines for Multinational Enterprises and Tax Administrations Part II. Applications (Draft text as of 1 March 1995)', Intertax, 1995/6-7, p. 312 et seq., paras. 134-144, especially the last one in relation to the 'no fault penalty' principle.

23 No. 25 of the commentaries on art. 10.3 MC OECD 1992.

24 No. 67 of the commentaries on art. 23 MC OECD 1992.

25 See commentaries nos. 67-69 on art. 23 MC OECD 1992, continuing in this point the doctrine exposed in paras. 8687 of the report 'La Sous-Capitalisation', op. cit. n. 15.

26 See no. 68 of the commentaries on art. 23A and B MC OECD 1992.

27 See no. 4 of art. 24 MC OECD 1992, as well as para. 56 of the commentaries, on the cited precept. 
'When either the direct or indirect indebtedness of a corporation with a non-resident person or company, and related to them in the context of paragraphs four and five of this article, exceeds the result when applying the coefficient, that is determined by regulation, to the figure of the fiscal capital the interest paid which corresponds to the excess will be considered fiscally as dividends.'

The coefficient has been established by the Second Additional Disposition of the Royal Decree $1841 / 91$ of 30 December, by which the Income Tax (IRPF) regulation is approved, being calculated as (2), ${ }^{28}$ except the companies that by legal duty could or should have a debt/equity coefficient that surpasses said ratio.

The thin capitalisation rules established in the Project of New Corporate Income Tax Law ${ }^{29}$ is almost identical to the preceding norm (Law 61/78). At this point it is important only to point out that in this regulation the indebtedness ratio has been calculated as (3), and that finance companies are excluded from the scope of said law.

In both cases there are standard thin capitalisation rules, in the aforementioned context, that balance the debt/equity objective method, in so far that if the ratio is surpassed the excessive interest will be treated as dividends for the borrower as well as for the lender.

The factors that give rise to the automatic application of the legal fiction (without possibility of proving to the contrary) established by Law 61/78, result from the existence of an indebtedness (direct or indirect) from a corporation resident in Spain with a linked non-resident person or company. Therefore the annual indebtedness exceeded as a result of applying the coefficient that is determined by regulation to the fiscal capital figure, will be treated fiscally as dividends.

The Project of New Corporate Income Tax Law introduces an important change in this field. Without doubt, this regulation tries to avoid the application of the DTC's non-discrimination clause by adding a new paragraph. Now, number four of art. 20 of the Project establishes that 'when there exists a DTC and subject to a reciprocity condition, the taxpayer could make a proposal to the Tax Administration in order to apply a different indebtedness ratio. The proposal must be based on the indebtedness level that the taxpayer would have obtained for independent persons in a free market situation.' Therefore this new paragraph introduces in some way a minimum contradiction principle in favour of the taxpayer. The aim of this rule is the compatibility of the thin capitalisation arrangement with the DTCs. However, as we shall see, this is not fully achieved.

In relation to the integrating elements of the supposed situation covered by this norm, the doctrine has stipulated the following specifications:

(a) The indebtedness to be taken into consideration is one which is as a result of any type of contract, excepting commercial operations that do not hide financing. ${ }^{30}$ It is the remunerated average indebtedness (annual) which is used to work out the debt/equity ratio or coefficient. ${ }^{31}$

(b) The indebtedness which is worked out includes that contracted directly as well as indirectly. Interpositions of independent people, such as back-to-back loans should also be taken into account. Although the doctrine does deny the relevance of loans guaranteed solely by a foreign parent company. ${ }^{32}$

(c) The lender must be a non-resident person linked to the borrower in the context of paras. 4 and 5 of art. 16 LIS. Given the extent to which this rule configures the link notion, the thin capitalisation rule will not only be applicable when the lender is a shareholder of the borrower, but rather, it is sufficient for there to exist an indirect or direct relationship of common control between the parties involved. Therefore this falls within the scope of art. 16.9 LIS (art. 20 of the Project of New LIS).

The non-resident condition of the lender must result in principle from the application of

28 It is possible to criticise the establishment of the ratio of thin capitalisation by a regulatory route, as long as it has substantive character for the configuration of the taxable fact and, as such, should have been approved through a norm with a range of law (arts. 8 and 29 of the General Tax Law (LGT)). This circumstance seems to be warned by the editors of the Project of New Corporation Tax Law (Boletin Oficial de la Cortes (BOF), no. 106-13 A, 6 October), insofar as art. 20.1 referring to the thin capitalisation has included the determination of the coefficient (3) in art. 20 of the aforementioned Project.

29) See art. 20 of the Project of New Corporation Income Tax Law (BOF no. 106-13 A, 6 October).

30) A. Rey Arnaiz, 'La subcapitalización', op. cit. n. 2 at pp. 492-494.

3 C. Palao Taboada, 'La subcapitalización y los DTC', op. cit. n. 2 at p. 90 , emphasises how the non-remunerated loans (without interest) are adjustable through art. 16.3 LIS. In the framework of the DTC that follows the MC OECD, the precept to invoke is art. 9, insofar as art. 11.6 is only applicable to excessive interest in relation to an arm's length situation.

32 See C. Palao Taboada, 'La subcapitalización y los CDI', op. cit. n. 2 at p. 90; V. Gonzalez Poveda, 'La subcapitalización: un problema nuevo en el IS', op. cit. n. 2 at pp. 82-85; Rey \& Collado, 'Aspectos físcales de la subcapitalización de sociedades: Derecho Comparado', op. cit. n. 2 at p. 89 et seq. 
Spanish fiscal legislation. ${ }^{33}$ Given that this law regulates the resident condition in Spain in a very wide form, it would not be unusual to find cases of double residence. In this case, it is appropriate to turn to the tie-breaker rules of the DTCs, or try to apply the criteria mentioned in the MC OECD to settle these problems. ${ }^{34}$ It is interesting to see that the Spanish legislator has opted to apply this anti-thin capitalisation norm only where the lender is a non-resident, something which can imply an unjustified difference in treatment. Because, on the one hand, this phenomenon could occur on an internal level, and on the other, it lacks any justification, following the reason for this norm (and to the exclusion of the previous hypothesis), that this operates in relation to the loans carried out by a permanent establishment located in Spain belonging to a non-resident corporation in favour of a resident of Spain.

We must also remember that the loan carried out by a branch office (permanent establishment) abroad of a financial corporation which is a resident of Spain, would also not. fall within the area of application of the Spanish thin capitalisation law (even if there is a link and ratio 2 or 3 is surpassed). Therefore, when there is a DTC which states that the revenue obtained by the permanent establishment in the other contracting State is exempt from the taxable income of its central office (the Spanish corporation), ${ }^{35}$ this could cause similar effects to the standard thin capitalisation cases. Or, what is more, could be even more advantageous because of the non-exaction of withholding tax on the interest by the borrower's country of residence. ${ }^{36}$

(d) The indebtedness coefficient is calculated on the average fiscal capital of the tax year, ${ }^{37}$ which equals the net corporate capital of the corporation. The calculation must be carried out separately for each of the creditors, something which, as C. Palao Taboada ${ }^{38}$ has indicated, opens a clear route for tax evasion for the integrating corporations of a similar group through the fragmentation of the loan.

The effect of this norm's application comes about when coefficient (2) or (3) is surpassed. ${ }^{39}$ This is usual with a thin capitalisation rule (as discussed above). It means, that in these cases the excessive interest will be considered and treated fiscally as dividends. In this context, the interest will not be deductible from the taxable income of the borrower, and it will be treated as dividends by the source State for the purposes of taxation.

In relation to the consequences derived from this norm for the collector of the 'dividends' it is necessary to distinguish different hypothesis:

(a) Non-resident person with a permanent establishment in Spain

The paid interest will make up the taxable income of the permanent establishment when it has been the one which carried out the loan. In this case, such revenue will attract taxation at a rate similar to that of a resident ( 35 per cent), and will enjoy similar deductions. ${ }^{40}$ Nevertheless, the fiscal charge can be increased when the profits are transferred abroad due to the existence of an additional tax of 25 per cent, ${ }^{41}$ unless such a transfer is made to its central office, which is a resident of a Community country. ${ }^{42}$

When DTCs exist between Spain and the State of residence of the central office of the permanent establishment located in Spain, the 'dividends' will sustain fiscal treatment similar to that explained in the previous paragraph. ${ }^{43}$ However, the exaction of the additional tax on revenues transferred abroad is excluded thanks to the operability of the non-discrimination

33 See arts. 9 LIS, 11-12 LIRPF, as well as art. 8 of the Project of New Corporation Income Tax Law.

34 See paras. $3^{\circ}$ (physical persons) and $4^{\circ}$ (legal persons) of art. 4 MC OECD 1992.

35 See for example, the DTC with the Netherlands, 16 June 1971 (art. 25.3) and with Switzerland, 26 January 1967 (arts. 21 and 23.1).

36 Nevertheless, the Committee of Fiscal Affairs, in the commentaries on art. 21.5 MC OECD, proposes an alternative solution to the contracting States in relation to the non-recoverability of withholdings at source on the revenues obtained by the permanent establishment from a resident person of the same State. See the OECD Fiscal Committee commentaries on art. 21.5. See also J.L. de Juan Peñalosa, 'Problemática tributaria internacional. Actuación a través de filiales y sucursales' in Estudios de Tributación Bancaria (Civitas, Madrid, 1985), especially p. 401; and of the same author 'Intereses' in Relaciones Fiscales Internacionales (IEF, Madrid, 1987), p. 262.

37 Articles 17.1 LIS and 164 et seq. RIS. See also the second number of art. 20 of the Project of New Corporation Income Tax Law (BOF, Spanish Parliament, no. 106-13 A, 6 October 1995).

38 C. Palao Taboada, 'La subcapitalización y los CDI', op. cit. n. 2 at p. 91.

39 Article 20.1 of the Project of New Corporation Income Tax Law (BOF, Spanish Parliament, no. 106-13 A, 6 October 1995).

40 Articles 23 and 24.7 LIS. Articles 48 to 55 of the Project of New Corporation Income Tax Law.

41 Articles 23.4 LIS and 51.2 of the Project of New Corporation Income Tax Law.

42 Article 22 of law 29/91, 16 December. Note that art. 51.3 of the Project of New Corporation Income Tax Law establishes the application of this exemption only when reciprocity occurs. This is contrary to EC law (nondiscrimination principle).

43 The location State of the permanent establishment must, in accordance with his reassessment, apply the internal measures of elimination of the double taxation on dividends according to art. 24.3 MC OECD 1992 (see the commentaries no. 29 et seq. on the cited precept). 
treaty clause, except when their own tax treaty does not include this arrangement ${ }^{44}$ or where the exaction of this charge was specifically authorised. ${ }^{45}$

(b) Non-resident lender without permanent establishment in Spain

When the recipient is a resident of a country with which Spain has not ratified a DTC, the dividends will sustain a withholding tax at source with a general charge of 25 per cent.

Where DTCs exist between the contracting States of the lender and borrower (which faithfully follows the doctrine that the OECD established in relation to this phenomenon ${ }^{46}$ ), a consensus solution that safeguards the harmony and internal coherence of these agreements could be reached, if the national thin capitalisation norm is compatible with the treaty. ${ }^{47}$

When this occurs the source State of the 'dividends' could apply withholding tax at the rate stipulated in the DTC for these revenues. Then, 'the State of residence of the lender would be obliged to give relief for any juridical or economic double taxation of the interest, as if the payment were in effect a dividend. It should then give credit for tax effectively withheld on this interest in the State of residence of the borrower at the rate applicable to dividends and, in addition, if the lender is the parent company of the borrower company, apply to such "interest" any additional relief under its parent company/subsidiary rules. ${ }^{, 48}$

It is necessary to point out that the difficult balance and consensus that the solution sanctioned by the OECD supposes, only has force where the DTC does not differ in a substantive manner from the MC OECD in relation to articles affected. This is also true where the national thin capitalisation norm is compatible with and, therefore, applicable within the DTC framework in the aforementioned context. This circumstance does not occur, as shall be seen below, in relation to the Spanish thin capitalisation regulation.

Finally, where the lender is a resident of a Community country, one may question the application of the Parent company/subsidiary Directive 90/435/EEC of 23 July 1990, in relation to the 'dividends' paid by the Spanish borrower corporation to the Community parent company (lender). In this context, the operability of this Community regulation in the reassessment of interest as dividends by anti-thin capitalisation procedures, presents obstacles that should be carefully analysed.

44 DTC with Australia.

45 DTC with the USA, Canada and Sweden.

46 The introduction (no. 33) of the MC OECD of 1992, as the commentaries on art. 9.1 (no. 2 in fine) urge the Member States to apply the existing treaties in the light of the new commentaries (dynamic or ambulatory interpretation). Nevertheless, H.J. Ault, 'The role of the OECD commentaries in the interpretation of tax treaties', Intertax, 1994/4, p. 144 et seq., warned that the interpretation of the DTC must generally follow the MC and commentaries pursuant to those which were negotiated, since the modifications in the commentaries, on many occasions, have substantial character. Nevertheless, commentaries (no. 2 in fine) on art. 9.1 seem to have surpassed this doctrine on thin capitalisation. This doctrine must be applicable to the DTCs negotiated on the 1963 and the 1977 OECD Models.

47 It is necessary to emphasise that, though a minority opinion which attributed an auxiliary character to these commentaries in the interpretation (preparatory projects), the international practice and the majority opinion agree in endowing to these texts a legally binding value, as an endowed interpretive agreement of the world consensus (see K. Vogel, Double Taxation Conventions, op. cit. n. 15 at pp. 33-36; P. Baker, Double Taxation Conventions and International Tax Law, op. cit. n. 15 at pp 28-31; D.R. Davies, Principles of International Double Taxation Relief (Sweet \& Maxwell, London, 1985), p. 52 et seq.; A. Miralulo, Doppia Imposizione Internazionale (Giuffré, Milano, 1990), p. 169 et seq.; H.J. Ault, 'The role of the OECD commentaries in the interpretation of Tax Treaties', op. cit. n. 46 at p. 44; Rhoades \& Langer, Income Taxation of Foreign Related Transactions, vol. 2 (Matthew Bender, New York, 1994), pp. 15-16; A. Xabier, 'Los problemas de calificación en el Derecho Tributario Internacional', $R D F H P$, nos. 225-226, pp. 667-668; J.L. de Juan Peñalosa, 'Doble Imposición Internacional. DTC' in Relaciones Fiscales Internacionales (IEF, Madrid, 1987), p. 81 et seq.; J.M. Farré Español, Doble Imposición Modelo 1992 (Einia, Barcelona, 1994), pp. 68-70; my work 'Algunas consideraciones en torno al os problemas de interpretación y calificación que plantean los DTC: análisis a la luz del nuevo MC OECD 1992', RDFHP, no. 229 , p. 135 et seq. Some outstanding authors such as K. Vogel (General Report of the Report IFA, Interpretation of Double Taxation Conventions (IFA, Kluwer, Netherlands, 1993), p. 156), assert that it 'would be recommendable that the DTC is transmitted to the commentaries on articles of the MC OECD as obligatory Directive for the interpretation of the same'. Furthermore, certain countries such as Switzerland and Germany have done this, so that in the DTC of 8 June 1971 between these countries a protocol was established that the OECD commentaries constitute the base for its interpretation (see J.C. Martinez, Les Conventions de Double Imposition (Litec, Paris, 1986), p. 56). Another example of the force or value of the commentaries on the MC OECD is how the proper jurisdictions and national administrative organs attend to these instruments almost systematically as general criterion or as a guide for the application of the DTC. See the resolutions of the Spanish tax administration RRDGT of 24 March 1982, 21 May 1987, 24 September 1991, 6 April 1987 (in Fiscalidad de No Residentes (Ciss, Bilbao, 1991), pp. 29, 260, 272 and 314, respectively) and 15 February 1994 (Circular MEH, no. 67, $1^{\circ}$ Semester 1994, pp. 125-126), as well as the RRTEAC of 29 September 1993 ( $Q F$, no. 26/93, p. 77), 7 June 1994 (JT 94, Ar. 983) and 7 June 1994, ( $Q F$, no. 18/94, p. 35).

Finally, it is suitable to warn that the reserves introduced by the States to the commentaries MC OECD do not constitute reserves in a strict sense (art. 2.1.d) of the Convention of Vienna on law of the Treaties, 23 May 1969 (BOE 13 June 1980)). This kind of reserve points out countries' attitudes about a given clause. See A. Borras, 'Los CDI desde el punto de vista de los tratados internacionales' in Estudios de Doble Imposición Internacional (IEF, Madrid, 1979), pp. $40-41$.

4x Number 68 of the commentaries of OECD Fiscal Committee on art. 23 A \& B MC OECD 1992. 
It is also necessary to underline that the effectiveness of the rules approved by Directive $90 /$ $435 /$ EEC is not affected by the force of a DTC that overlaps its operative area with the Directive. ${ }^{49}$ As we know, the Directives are configured with the character of High Law or Community primacy over national legislation of the Member States of the European Union. ${ }^{50}$ Thus, when a rule of DTCs violates a Community norm in a way that imposes a negative limit (for example, non-discrimination) this article will be inapplicable ${ }^{51}$ and will thereafter be eradicated from the Law of the Member State (art. 5 EC Treaty). ${ }^{52}$ Where there is a Community positive limit, such as a Directive that establishes the exclusion of the charge on a given taxable fact, the DTCs that juxtapose their fiscal rules must remain inapplicable on the basis of Community primacy.

Nevertheless, in some situations where there is an overlap in Community procedures and DTCs, the fiscal rules of the double taxation agreement could, on the whole, be more favourable for the taxpayer than the Directive. This would occur when they sanction an inferior tax rate or certain conditions which are less strict for the application of a given benefit (parent company/ subsidiary) or simply because they (the DTCs) guarantee a more favourable solution in a given case. In this hypothesis it is justifiable that the taxpayer should decide to apply the DTC rules provided that the conventional regulation does not infringe the intended objectives of the Community arrangement. ${ }^{53}$ This is especially applicable in relation to Directive 90/435/EEC on thin capitalisation matter where, due to the lack of bilaterality in the assessment of the revenues (the interest reassessed as dividends) economic double taxation takes place, something which is clearly opposite to the purpose of the Directive; while the DTCs in some instances guarantee the elimination of the effects of the said phenomenon, which is more favourable both to the taxpayer and to the European Community, insofar as it suppresses a fiscal obstacle to the accomplishment of the interior market. We should point out that Directive 90/435/EEC specifically establishes the possibility of applying simultaneously and alternatively the arrangements of the DTCs. ${ }^{54}$ The Community Justice Court of Luxembourg has confirmed this same interpretation, analysing the relations that mediate between bilateral tax treaties (of Social Security) ${ }^{55}$ and Community Regulation no. 1408/71, of the Council.

Referring briefly to the substantive conditions for the application of the Parent company/ subsidiary Directive to the case of interest reassessed on 'dividends' by virtue of national thin capitalisation procedures, it is necessary to emphasise the need for concurrence on the following.

49 The same interpretation applies in relation to laws that the Directive implemented (Law 29/91, 16 December) inasmuch as it also constitutes EC law.

50 See arts. 189 and 234 EC Treaty, as well as the ECJ decision of 5 February 1963, Case 26/62, Van Gend and Loos, ECR, p. I-9 et seq.; 15 July 1964, Coast/Enel, Case 67/64, ECR, p. I-1162 et seq.; 17 May 1972, Leonesio, ECR, p. I2967 et seq.; 27 February 1962, Commission/Italy, Case 10/61, ECR, p. I-1; and 14 February 1980, Burgoa, Case 819/ 79, ECR, p. I-2787. See J.V. Louis, El Ordenamiento Juridico Comunitario (Perspectivas Europeas, Brussels, 1991), p. 112 et seq.; J. Boulois, Le Droit des Conmunautés Europénnés (Recueil des Cours de l'Academie de Droit International, 1992), vol. IV, (235), pp. 66-74.

51 L. Hinnekens, 'Compatibility of Bilateral Tax Treaties with EC Law. The Rules', EC Tax Review, 1994/4, p. 147 et seq.

52 See A. Mangas Martin, 'La obligación de derogar o modificar el Derecho interno incompatible con el Derecho Comunitario: evolución jurisprudencial', Revista de Instituciones Europeas, vol. 14, no. 2, 1987, p. 314 et seq.; R. Girbau Pedragosa, 'Ley Fiscal española y primacía comunitaria', Impuestos, no. 22, 1993, p. 25 et seq.

53 See F. Vanistendael, 'The implementation of the Parent company/Subsidiary Directive in the EC - Comments on some unresolved questions', Tax Notes International, 21 September 1992, p. 602; F. de Hosson, 'The Parent Company/Subsidiary Directive', Intertax, 1990/10, pp. 414, 427, 434-435; A. Manganelli, 'Italian Ministry issues regulation on dividend tax refunds under Parent company/Subsidiary Directive and Tax Treaties', Tax Notes International, vol. 9, 1994/15, pp. 1103-1108; J.M. Cougnon, The EEC Merger and Parent Company/Subsidiary Directives of 23 July 1990 (Bruylant, Brussels, 1992), pp. 127-147, 213 et seq.; J. Hernaez and F. Echevarria, 'Régimen fiscal común aplicable a las sociedades matrices y filiales de Estados miembros de la CEE', $Q F, 1993 / 9$, p. 115 .

54 See art. 3.6 of Directive 90/434/EEC and arts. 1.2, 2b, 3.2 and 7.2 of Directive 90/435/EEC. Of the same opinion are: E. McGregor, 'Implementation of the EC Parent company/Subsidiary Directive in the various member countries', $I B F D$, July 1992, p. 340 et seq.; N. Raby, 'National Implementation of the Parent company/Subsidiary Directives: some problems and opportunities identified', EC Tax Review, 1992/4, p. 219. Also, in relation to Spain the derogation of art. 21 of Law 29/91 of 16 December, by the Derogatory Disposition of law 42/94 of 31 December, can be saved through the designated 'interpretation of the national Law in the light of the Community Law' (ECJ, 20 October 1987, Oberkreisdirektor Kreisses Borken, Case 190/87, Recp. I-4722 et seq.; 21 March 1991, Rauh, Asunt 314/89, ECR, p. I-1647 et seq.; 25 November 1986, Klensah, Case 201 and 202/85, ECR, p. I-3477 et seq.). This idea is especially applicable bearing in mind that this law is a national implementation of Directive 90/435/EEC. On this last interpretive issue see C. Lewis \& S. Moore, 'Duties, Directives in European Community Law', Public Law Review, 1-212 (793), pp. 13-156; W. Schick, 'Sobre dos problemas del Derecho Fiscal alemán: retroactividad y los conflictos entre el Derecho Europeo y el Derecho fiscal nacional', Crónica Tributaria, no. 56, pp. 184-185; Pellicer Zamora, 'Condiciones y tipos de invocabilidad de la Directiva Comunitaria', Revista de Instituciones Europeas, vol. 12 , no. 1,1985 , p. 60 et seq.

55 ECJ, 7 February 1991, Rönfelt, 227/89, ECR, p. I-323 et seq., especially points 25-29. 
Subjective scope: ${ }^{56}$

- The corporations should carry some of the legal forms established in the supplement of the Directive. ${ }^{57}$

- The corporations should have fiscal residence in different countries of the EU, excluding those that by virtue of the tie-breaker rules of DTCs with a third country were considered to have residence outside the EU. ${ }^{58}$

- The two corporations must be subject to the taxes that the corporation's profits encumber. The presence of partial exemptions does not distort such a general condition in the opinion of the Spanish Tax Administration. ${ }^{59}$

- There is the possibility of excluding the Directive on certain subjects by applying national or conventional norms necessary to avoid fiscal abuses or frauds. ${ }^{60}$

- The fiscal rules established in the Directive are applicable where, all other requirements being met, the assets, the object of the loan, are affected by a permanent establishment located in a Community country that, operating as lender, is the effective beneficiary of the interest reassessed as 'dividends'. Nevertheless, in this case the economic double taxation on the dividends will not be totally eliminated, even though the withholding tax is suppressed at source. The measures that the Directive establishes to suppress the effects of this phenomenon at present are only applicable by the State of residence of the parent company. ${ }^{61}$

Objective scope: ${ }^{62}$

- The Directive is applied to distributions of corporate profits by subsidiaries to the parent company for motives or causes different to the liquidation of that company. ${ }^{63}$ In this context, nothing seems to block the application of the Directive to the interest distributions reassessed as dividends by virtue of national thin capitalisation arrangements, as long as the other requirements are met. The subsidiary must be the borrower and the parent company the recipient of the 'dividends' in order for the rules of the Directive to be applied, inasmuch as art. 4 of said Directive demands that the parent company corporation receive the dividends 'as shareholder'. Therefore the operability of this norm on thin capitalisation is clearly limited. A good test of the application of the Directive to these cases is given by the Spanish implementation of the Directive, as long as this possibility is specifically established under certain conditions. ${ }^{64}$

56 See arts. 1, 2 and 3 of Directive 90/435/CEE, and art. 17 of law 29/91 of 16 December (in the text of the application of the 4' Additional Disposition of law 42/94, of 30 December). See also arts. 30 and 46.1.f) of the Project of New Corporation Income Tax Law. Note that the derogatory disposition of the mentioned project deletes Titles 1 and 2 of law 29/91.

57 Nevertheless, art. 23.1 of law 29/91, of 16 December, establishes that, subject to the reciprocity condition, the MEH (Tax Administration) will be able to extend the application of the Directive to corporations that carry a different legal form from the withdrawal in the annex of the Directive. In the same way, see art. 46.1.f) of the Project of New Corporation Income Tax Law. Note that, neither law 61/78 (art. 24.5), nor the Project of Corporation Tax Law (art. 30), requests this formal element when the parent company is resident of Spain, but this condition should be requested by the source State.

58 Article 24 Law 29/91, 16 December, and art. 46.1.f) Project of New Corporation Income Tax Law.

59 Thus it has been understood by the Spanish Tax Administration (DGT) in the resolution of 16 July 1992 (Regulation $\mathrm{MEH}, 2^{\circ}$ Semester 1992, p. 136).

60 Article 1.2 of Directive 90/435/CEE, art. 24 Law 29/91, of 16 December. In relation to this last disposition see the resolution of the Spanish Tax Administration (DGT) of 16 July 1992 (Aranzadi Fiscal, IS, Tomo 2, DGT, no. 85). See also art. 46.1.f) of the Project of New Corporation Income Tax Law. According to this last norm corporations controlled by non-residents in the EU, as well as parents resident in tax haven countries are excluded from the Directive's scope.

61 See arts. 4 and 5 of the Directive, arts. 17, 18, 20 and 22 of law 29/91, of 16 December, and arts. 30 and 51.4 of the Project of New Corporation Income Tax Law. See F.A. Garcia Prats, 'Application of the Parent Company/ Subsidiary Directive to Permanent Establishments?', European Taxation, vol. 35, no. 6, 1995, p. 179 ff.; F. Vanistendael, 'The implementation of the Parent company/Subsidiary Directive in the EC - Comments on some unresolved questions', op. cit. n. 53 at pp. 602-603.

62 See arts. 1, 2, 3 and 4 of Directive 90/435/CEE, and arts. 17, 18.3 and 20 of law 29/91, of 16 December (in the text of the application of the $4^{\mathrm{a}}$ Additional disposition and the Derogatory Disposition of law 42/94, of 30 December). See also art. 46.1.f) of the Project of Corporation Income Tax Law.

63 Article 4.1.d) Directive 90/435/CEE, art. 17.1.b) Law 29/91, 16 December and art. 46.1.f)b) of the Project of New Corporation Income Tax Law.

64 The Spanish Tax Administration does not only seem to be in favour of applying the rules of the Directive when the subsidiary is the one which distributes the reassessed 'dividends' suppressing here the withholding at source, but also when it is the parent company resident of Spain which receives these revenues from a company which is a resident of another Member State. Nevertheless, in this last hypothesis, para. $2^{\circ}$ of art. 23 of law 29/91 of 16 December establishes two conditions in order to apply thin capitalisation reassessments in this field. First, reciprocity of the other Member State, secondly, according to what was established in art. 16.9 LIS it might have corresponded the same assessment (to the excessive interest reassessed as 'dividends' by the source State). Note that the Repealing disposition of the Project of New Corporation Income Tax Law abolishes or deletes Titles 1 and 2 of law 29/91. This 
- There is a tendency to agree that the legal title that enables one to benefit from the rules of the Directive is the legal ownership, i.e. the tenure as owner of the title of the sharing participation in the share capital of the subsidiary. It is not sufficient, therefore, to exhibit real rights over the shares as the usufruct. ${ }^{65}$ Nevertheless, the tenor of art. 4 of the Directive is very ambiguous on this point, so the most suitable thing would be to outline this problem before the European Court of Justice (hereafter ECJ) in order to obtain a uniform response.

- The parent company/subsidiary link is present when the parent company possesses a minimum of 25 per cent direct participation in the capital of the subsidiary during a noninterrupted period of two years. Nevertheless, the States can reduce or substitute these conditions. ${ }^{66}$

In view of the necessary requirements for the application of the parent company/subsidiary Directive on thin capitalisation cases, one must believe that these rules will operate only on certain occasions. The advantages derived from the Directive in these cases are not very convincing. This is caused either by the fact that when the Directive was drafted it was not thought about or there was not sufficient consensus to specifically define the conditions for its application to the thin capitalisation cases. Therefore, even though the extent of the Directive seems to permit its operability there, the results of this application do not seem to be suitable to the task of the Directive.

Let us consider a case where, following the requirements demanded by the Directive, a subsidiary pays to its Community parent company some interest reassessed thereafter as dividends by virtue of a national thin capitalisation arrangement. On the basis of the Community norm, the State of residence of the subsidiary excludes all taxation at source on the 'dividends' ${ }^{67}$ Nevertheless, the State of residence of the parent company (recipient of the 'dividends') is not, at first, linked by this assessment, inasmuch as this situation is not specifically established in the Directive. Therefore, the most common situation will be that said revenues will be treated by the parent company as interest, thus attracting economic double taxation. This phenomenon goes against the intention of the Directive, since it is precisely one of the effects that the Directive tries to suppress due to the distortions that originate in the interior market.

A good example of the qualifying asymmetry that can be produced in these cases is provided by the Spanish implementation of the Directive, ${ }^{68}$ i.e. when a Spanish parent company receives from its European subsidiary interest reassessed as dividends in the country of source. Article 23.2, Law 29/91 of 16 December, establishes that the taxable income of the Spanish parent company would only be considered as dividends and, consequently, benefit from the fiscal rules which apply to a parent company/subsidiary, by meeting two requirements. First, in accordance with the applicable Spanish regulation (art. 16.9 LIS) the same assessment would have to correspond to it. Secondly, the source State (of the dividend) grants reciprocally the same treatment to the interest reassessed under Spanish law. ${ }^{69}$

cont.

project does not establish a special regulation for the application of the parent/subsidiary rules to the thin capitalisation field. Then, when this project is in force as the new Corporation Tax Law, only the Spanish thin capitalisation reassessments will have effects on the application of the Directive (the exclusion of the withholding tax on 'dividends' in Spain).

65 See F. Vanistendael, 'The implementation of the Parent company/Subsidiary in the EC', op. cit. n. 53 at pp. 606-607; F. de Hosson, 'The Parent company/Subsidiary Directive', op. cit. n. 53 at p. 439. Also, E. Blasio, R. Cecherinni, F. Monaco, Tassazione e Controllo Sozietario nella CEE (EBC, Milano, 1993), pp. 17-18, 26 et seq., they emphasise the exclusion of the usufruct of the coverage of the Directive in Italian Law by virtue of law 492/92. The Spanish Tax Administration in resolution (RDGT) of 8 June 1992 (Regulation MEH, 20 Semester 1992, p. 113) excluded the benefit of the Directive, i.e. the distributions accomplished in favour of the usufructuary.

66 Article 3 and 3.1 of Directive 90/435/EEC, art. 17.2 of law 29/91, 16 December and arts. 46.1.f and 30 of the Project of New Corporation Income Tax Law. The Spanish subsidiary/parent rule requires a 25 per cent minimal direct participation during a one year non-interrupted period; whilst the parent/subsidiary arrangement needs 5 per cent over a one year minimal participation period.

67 Nevertheless, Austria denies the exclusion of the withholding tax when there is a hidden distribution of dividends. See M. Jann, 'The implementation of Direct and indirect tax Directives in Austrian Tax Law', EC Tax Review, 1995/3, p. 144.

68 See J. Hernaez \& F. Echevarria, 'Régimen fiscal común aplicable a las sociedades matrices y filiales de Estados miembros de la EEC. Aplicación al Derecho Fiscal español de la Directiva 90/435/EEC', op. cit. n. 53 at p. 109.

69 Note that the annulment disposition of the Project of Corporation Law abolishes titles 1 and 2 of law 29/91. This project does not provide new rules on these cases. In the future only the interest reassessed as 'dividends' will have effect in the application of the Directive when the reassessment was made by the Spanish tax authorities. 
This lack of co-ordination of tax powers could be solved by applying the 90/436/EEC Convention. ${ }^{70}$ This international treaty ${ }^{71}$ seems to have been conceived especially to solve the economic double taxation problems produced as a consequence of fiscal adjustments (not correlative) on associated companies that operate with transfer prices. Nevertheless, from a systematic interpretation of arts. 1, 4 and 6 through to 14 of the Agreement, nothing prevents this international treaty from being applied to thin capitalisation adjustments in order for the competent authorities that suppress the double taxation to reach an agreement. ${ }^{72}$

This is possible on the basis of two arguments. First, the 90/436 Convention, as well as the thin capitalisation arrangements, present the common task of obtaining an arm's length taxation. Secondly, it can be argued that following the literal tenor of art. 4.1.a) of the Convention, the application of the convention to these cases can be invoked inasmuch as this article establishes that:

'The application of the present agreement will be governed by the following principles:

1) When:

a) a company of a contracting State participates directly or indirectly in the management, the control or the capital of a company of another contracting State, or when

b) the same people participate directly or indirectly in the management, the control or the capital of a company of a contracting State,

and when, in one of these cases the two companies, in their financial or commercial relations, are linked by agreed conditions different to those which would be agreed between independent companies. The profits of one of the companies, in the case that had they not existed these conditions would have been made, could be included in said company's profits and consequently be taxed.'

As such, the mutual agreement and arbitral procedure established in this treaty would be useful in solving the existing discrepancies between fiscal authorities in connection with the assessment, and treatment of the interest reassessed as dividends, by virtue of national thin capitalisation procedures. Thus removing the economic double taxation brought on by this fiscal asymmetry. The application of this Convention not only can take place where the rules of Directive 90/435/ EEC operate, but also when this disagreement is within the scope of a DTC between Member States of the European Union that have ratified the $90 / 436$ Convention (inasmuch as the procedure of administration agreements of this Convention is technically more complete and effective than the one established by the DTCs: art. 25 MC OECD). ${ }^{73}$

In fact, neutrality in the application of the national thin capitalisation procedures in the sense of the elimination of economic double taxation on the dividends, as with most problems of international taxation, requires an important level of co-ordination between the tax powers. It is evident that when there is not (at least) a minimal consensus between the involved States that guarantee the symmetry in the assessment and fiscal treatment of the reassessed revenues, the cited phenomenon will inevitably emerge.

In this sense, when there are no DTCs between the involved States there will probably be economic double taxation, unless the competent authorities of the said States come to an agreement. Where a DTC exists and the national thin capitalisation rule is applicable and compatible with the DTC, we understand that the solution arbitrated by the Committee of Fiscal Matters OECD would generally guarantee the assessment symmetry necessary to avoid

70) EC Journal, L. of 20 September 1990. Spanish ratification by instrument of 10 April 1992 (BOE of 21 December 1994, no. 304). It is necessary to indicate, also, that this Agreement has come into effect for the 12 Community countries as of 1 January 1995 after ending the ratification process. The new members of the European Union, on the basis of art. 4 of the adhesion Treaty to the Community, can accede to the Agreements based on art. 220 EC Treaty. The last notice that we have found is that Finland ratifies the Convention: see T. Viherkentta, 'The implementation of the EC Tax Directives in Finnish Law', EC Tax Review, 1995/3, p. 150.

71 It is necessary to insist on the nature of the international treaty of this instrument excluding its Law between the sources of the Community Law, inasmuch as it has been the States which have negotiated, signed and ratified on the basis of their treaty making power. See L. Millan Moro, La armonización de legislaciones en la CEE (Centro de Estudios Constitucionales, Madrid, 1986), p. 145 et seq.; Terra \& Wattel, European Tax Law (Kluwer, Boston, 1993), p. 209 et seq.; Y. Kergall, 'Double taxation: an assessment of the last EC proposals in the light of existing rules implemented by national laws and bilateral treaties', Intertax, 1990/10, p. 448 et seq.; D. Shelpe, 'The arbitration convention: its origin, its opportunities and its weaknesses', EC Tax Review, 1995/2, p. 71. By contrast, A. Borras, 'Los convenios complementarios entre los Estados miembros de la EEC', Noticias CEE, 1986/12, pp. $115-118$ and M.A. Sanchez Jeménez, La doble imposición internacional en la UE (La Ley, Madrid, 1995), pp. 52-54, consider EC law the agreements signed based on art. 220 EC Treaty.

72 Of a similar opinion seems to be J. Killius, 'The EC Arbitration Convention', Intertax, 1990/10, pp. 442-443. See also V. Gonzalez Poveda, 'Convenio relativo a la supresión de la doble imposición en caso de corrección de los beneficios de empresas asociadas', Noticias EEC, 1991/74, pp. 16-17.

73 Agreement $90 / 436$ must be applied as the lex specialis. We believe this interpretation seems to be detached from art. 15 of Convention 90/436. Of a similar opinion is L. Hinnekens, 'Compatibility of Bilateral Tax Treaties with EEC Tax Law. The rules', op. cit. n. 51 at p. 61 , note 45 . In a similar context see the decision of the EC Court of 26 December 1994, Tatry, ECR, pp. I-439, on the relations between the Brussels Convention of 1968 and other treaties. 
economic double taxation. When Directive 90/435/EEC is applied to these cases, the most frequent result would be the lack of necessary co-ordination to grant unitary fiscal treatment to the 'dividends' and, therefore, the cited phenomenon will arise. In this last hypothesis, the rules anticipated in the DTCs will generally be more advantageous. Only where the discrepancies between the fiscal Administrations make it impossible to apply the solution that the OECD Fiscal Committee established in the framework of the DTCs, would it be more convenient to follow the rules of the Directive, in conjunction, if necessary, with the mutual agreement and arbitral procedure stipulated by the $90 / 436$ Convention.

\section{Examination of the Compatibility of the Spanish Thin Capitalisation Arrangement with the DTCs and EC law}

\section{A. Analysis of Spanish Thin Capitalisation in Relation to the DTCS}

\section{Incidence of the non-discrimination principle}

Article 24.4 of the $\mathrm{MC} \mathrm{OECD}{ }^{74}$ does not prohibit the country of the borrower from treating interest as a dividend under its domestic rules on thin capitalisation insofar as these are compatible with para. 1 of art. 9 or para. 6 of art. 11. However, if such treatment results from rules which are not compatible with the said articles and which only apply to non-resident creditors (to the exclusion of resident creditors), then such treatment is prohibited by para. 4 .

The compatibility of the Spanish thin capitalisation regulation with art. 9.1 MC OECD is more than questionable insofar as it uses the method of the indebtedness fixed ratio without allowing the taxpayer to prove the existence of a free market situation. In this sense, the OECD Committee of Fiscal Matters, ${ }^{75}$ as well as the scholar studies ${ }^{76}$ agree in asserting that the mentioned objective method can provide an indicium of thin capitalisation existence, but in no case does it constitute an indisputable test to consider the existence of this phenomena. As a result it is understood that for the system of fixed indebtedness ratios to be in accordance with the arm's length principle all the circumstances of the case (i.e. the sector and the market) must be examined, always permitting the taxpayer to prove the concurrence of free competition between independent parties in the market.

As such, the OECD Fiscal Committee ${ }^{77}$ has declared that art. 9.1 'does not prevent the application of national rules on thin capitalisation insofar as their effect is to assimilate the profits of the borrower to an amount corresponding to the profits which would have been accrued in an arm's length situation' as well as that 'the application of rules designed to deal with thin capitalisation should not normally have the effect of increasing the taxable profits of the relevant domestic enterprise to more than the arm's length profit, and that principle should be followed in applying the existing tax treaties'. Therefore, everything seems to point to the non-application of the Spanish regulation where there exists a DTC that takes up the nondiscrimination principle following art. 24.4 MC OECD 1992. What this means is that the examination of the Spanish regulation in light of art. 24.4 MC OECD reveals the concurrence of two elements required by this rule. This domestic legislation will not be applied in the DTCs framework, because, on the one hand, there is a breach of the principles of arts. 9.1 and 11.6 and, on the other hand, the operability of the cited norm occurs only where the lender is a nonresident. $^{78}$

Other arguments of this interpretation come from the analysis of other passages of the

74 See no. 55 of the commentaries on art. 24.4 MC OECD 1992.

75 OECD, 'La Sous-Capitalisation', op. cit. n. 15, particularly para. 79, as well as the commentaries on arts. 9.1, 11.6, 23 (no. 67 et seq.), 24.4 and 5 MC OECD 1992.

76 See C. Palao Taboada, 'La Subcapitalización y los CDI', op. cit. n. 2 at p. 84 ff., 92 ff.; V. Gonzalez Poveda, 'La subcapitalización: un problema nuevo en el IS', op. cit. n. 2 at pp. 84-91; Rey \& Collado, 'Aspectos fiscales de la subcapitalización de sociedades', op. cit. n. 2 at pp. 78-79, $93 \mathrm{ff}$.

77 Number 2 of the commentaries on art. 9.1 MC OECD 1992.

78 See C. Palao Taboada, 'La subcapitalización y los CDI', op. cit. n. 2 at p. 84 et seq., p. 92 et seq.; V. Gonzalez Poveda, 'La subcapitalización: un problema nuevo en el IS', op. cit. n. 2 at pp. 84-91; Rey y Collado, 'Aspectos fiscales de la subcapitalización de sociedades', op. cit. n. 2 at pp. 78-79, 93 et seq.; N. Del Castillo, R. Mullerat, R. Rodroguez, 'A review of Spain's thin capitalization rules', Tax Notes International, vol. 9, no. 15, 1994, pp. 11131116; Gutierrez Sanchez, Regife Longedo, Tomas Hernandez, 'Aspectos internacionales de la evasión y el fraude fiscal', op. cit., p. 12 ff., p. 16 et seq.; G. Gutierrez de Pablo, 'Diversos aspectos de la planificación fiscal internacional y el uso de los paraísos fiscales. Análisis de algunas medidas de prevención', op. cit. n. 2 at pp. 25-26; S. Raventos Calvo, 'The Treaty shopping in the last DTC signed by Spain', Revista de la Economia Social y de la Empresa, 1995/ 21, pp. 73-75; A. Veldt, 'A new Spanish legislation against thin capitalization for Spanish companies with nonresident shareholders only', Intertax, 1992, p. 293 et seq. 
OECD Report on thin capitalisation ${ }^{79}$ as well as from the commentaries made to the MC OECD ${ }^{80}$ Here it is asserted that even the demand for the taxpayer to prove some of the conditions of the existence of an arm's length situation if they turn out to be too rigid or disproportionate can also infringe art. 9.1 and, therefore, be inapplicable in the scope of a DTC that takes up the non-discrimination clause. In this sense, when the Spanish norm establishes an automatic legal fiction without the possibility to test to the contrary where the indebtedness ratio is surpassed, there is a violation of the principles taken up in art. 9 MC OECD.

The Project of new Corporate Income Tax Law introduces an important change in this matter. According to no. 4 of art. 20 of the project, the taxpayer can demonstrate in some way the measure of his indebtedness ratio to the arm's length principle. ${ }^{81}$ The aim of this rule is that the Spanish thin capitalisation arrangement can be applied in the scope of the DTCs without affecting the non-discrimination principle (art. 24 MC OECD). Prima facie this article carries out this objective. Nevertheless, a deeper study of this regulation shows some problems in fulfilling that goal. On the one hand, this rule does not allow the taxpayer to disprove, by following all the circumstances in the case, that his indebtedness ratio is in accordance with the arm's length principle. On the contrary, the Project only permits the taxpayer to make a 'proposal' to the Spanish Tax Administration in order to apply a different ratio of the general coefficient established in the first paragraph of the norm. It is also important to point out that this 'proposal' (only) 'will be founded in the indebtedness that the taxpayer could have obtained from independent persons in the market'. According to this limitation, we believe that in some cases the taxpayer, as a result of the application of this rule, could suffer a tax charge that surpasses the arm's length taxation and as noted, this consequence is contrary to arts. 9.1 and 24.4 MC OECD.

It is important to remember that the OECD Fiscal Committee established that all the circumstances present in the case must be analysed in order to fix the market indebtedness ratio of a taxpayer. Also, the OECD explained, with respect to the objectives methods (fixed ratio), that these are only in accordance with the arm's length principle when the taxpayer can demonstrate (without limitations) that his indebtedness ratio is a market ratio or the measure of the adaptation to this principle. ${ }^{82}$ Therefore, when the domestic thin capitalisation rules do not fulfil these conditions they are contrary to arts. 9.1 and 24 MC OECD.

Another point made in the Project that is not in line with these articles, as well as with the OECD doctrine is from the reciprocity (of the other contracting State) required by the Spanish rule as a condition for allowing the taxpayer to make that 'proposal'. Certainly, neither the OECD Report, nor the Model Convention commentaries permit the contracting States to limit or restrict the taxpayer's rights and the accomplishment of the arm's length principle to the achievement of the reciprocity condition. ${ }^{83}$ As such this requirement is also contrary to arts. 9.1 and $24 \mathrm{MC}$ OECD.

In a case where a permanent establishment of a resident-linked company of another contracting State is located in Spain, and is the one which in fact carried out the loans to the resident corporations of Spain, Law $61 / 78$ as well as the Project of Corporation Income Tax Law violates the non-discrimination principle. Other demonstrations of the principle taken up in art. $24 \mathrm{MC}$ OECD succeed in establishing the fiscal equality between the resident companies of a contracting State and the permanent establishments of a resident company of the other contracting State that are located in the territory of the first State. One of the conditions that the Committee of Fiscal Matters demands so that the clause of para. 3 of art. 24 MC OECD (1992, 1995) could operate is that the equality in treatment can only be referred to as a contrast to the permanent establishment with resident companies that carry out the same type of activities in the same economic sector. ${ }^{84}$ This condition is present in the Spanish thin capitalisation norm, since it operates indiscriminately in relation to all types of loans contracted with non-residents

79 OECD, 'La Sous-Capitalisation', op. cit. n. 15 at para. 79.

80 See no. 4 in fine of the commentaries on art. 9.1 MC OECD 1992.

81 See art. 20.4 of the Project (BOF Parliament, no. 106-13 a, 6 October 1995).

82 See para. 25.i) ii) of the report 'La Sous-Capitalisation', op. cit n. 15 as well as nos. 2-4 of art. 9.1 MC OECD.

83 The OECD Fiscal Committee ('Transfer Pricing Guidelines for multinational Enterprises Part II. Applications', Intertax, 1995/6-7, p. 312 et seq.) declared that '133. In practice, neither countries nor taxpayers routinely misuse the burden of proof in the manner described above. Still, because of the difficulties of transfer pricing analysis, it would be appropriate for both taxpayers and tax administrations to take special care, and to use restraint in relying on the burden of proof in the course of the examination of a transfer pricing case. More particularly, as a matter of good practice, the burden of proof should not be used by tax administrations or taxpayers as a justification for making groundless or unverifiable assertions about transfer pricing. A tax administration should be prepared to make a good faith showing that its determination for transfer pricing is consistent with the arm's length principle even where the burden of proof is on the taxpayer. Similarly, taxpayers should be prepared to make a good faith showing about their transfer pricing regardless of where the burden of proof lies.'

x4 See no. 19 et seq. of the commentaries on art. 24.3 MC OECD 1992 
(linked). The difference in fiscal treatment of the non-resident lenders that operate with a permanent establishment in Spain penalises these economic operators in contrast to the residents that carry out the same operations. Therefore, the norm establishes a discrimination and contradicts art. 24.3 MC OECD $(1992,1995)$ and, must be inapplicable in these cases. ${ }^{85}$

At the same time, the difference is arbitrary if we consider that the possibilities of tax evasion or tax collection loss that exist in this hypothesis for the Spanish Exchequer are identical to those which exist when the situation is internal, i.e. when both the lender and the borrower are residents (linked) of Spain. This is because (as we know), the permanent establishment, whether DTCs mediate or not, is subject to tax in Spain on the world-wide income obtained by the permanent establishment.

The Spanish thin capitalisation rule established in Law 61/78 is incompatible with the nondiscrimination principle, and would only be applicable in DTCs with Australia, the former USSR, Ireland, Argentina, Mexico and Portugal. This is because the first two cited agreements are separated from the MC OECD by not including the non-discrimination principle. ${ }^{86}$ The others establish clauses in the Protocols specifically sanctioning the application of the Spanish thin capitalisation legislation without invoking the non-discrimination principle to request its exclusion. ${ }^{87}$ The thin capitalisation regulation approved by the Project of Corporation Income Tax Law would only be compatible with arts. 9.1 and 24.4 when the Spanish Tax Administration allows more flexibility within the system and conditions in allowing the taxpayer to demonstrate the fulfilment of the arm's length principle. Finally, it is necessary to point out that the thin capitalisation rule of the Law $61 / 78$ as well as the Project of New Corporation Income Tax Law contradicts art. 24.3 MC OECD.

\section{Incidence of the national treatment clause of the companies under foreign control}

Paragraph 5 of art. 24 MC OECD 1992 (art. 24.4 MC OECD 1977) sanctions a clause that could also be relevant to the object of excluding the thin capitalisation procedures. This rule prohibits a contracting State from granting a less favourable fiscal treatment to a company whose capital is exhibited (owned) or controlled, totally or partially, directly or indirectly, by one or more residents of the other contracting State. This arrangement and the discrimination to which it puts an end refers solely to the taxation of companies and not to persons that possess or control their capital. This is because the object of para. 4, art. 24 is to assure the equality of fiscal treatment between resident contributors in the same State and not to hold foreign capital in the participant's and shareholder's hands to identical treatment as that applied at a national level. ${ }^{88}$

In this sense, this norm prohibits a resident company of a State that is found in similar circumstances $^{89}$ to another resident company of the same State being subject to more aggressive fiscal rules than those mentioned above. The discrimination must be based on the circumstance that the property or control of these companies is, totally or partially, directly or indirectly, in the hands of residents of the other contracting State. ${ }^{90}$

It is important to mention, nevertheless, that the OECD report 'Traitement National des Enterprises sous Côntrole Étranger' $(1993)^{91}$ has shaded the previous affirmations. Considered to be compatible with this principle is the establishment of certain steps intended to guarantee safety, public order and the national interest. In this sense, in relation to the procedures against tax evasion (considered by some to be those of thin capitalisation), "the fact of establishing measures that sanction charges of the strictest test to the companies within a multinational group for the sake of avoiding fiscal evasion cannot be considered as a discriminatory measure in relation to the companies under foreign control'. Nevertheless, this statement has been the

85 See no. 29 et seq. of the commentaries on art. 24.3 MC OECD 1992.

86 The DTC with Australia omits totally art. 24 MC OECD, while the Agreement with the USSR is separated from the MC OECD in its art. 21, which does not include paras. $4^{\circ}$ and $5^{\circ}$ of the MC OECD 1992.

87 See no. 6 of the Protocol at the DTC with Ireland, no. 8 of the Protocol at the tax treaty with Argentina, no. 5 of the Protocol with Mexico and no. 4 of the Protocol of the new DTC with Portugal (26 November 1993) (published in the Official Bulletin, 7 November 1995).

88 Number 57 of the commentaries on art. 24.5 MC OECD 1992.

89 K. Vogel, Double Taxation Conventions (Kluwer, the Netherlands, 1990), p. 1148, has underlined that the appraisal of the similarity of circumstances must be accomplished in comparison with a company that operates in the same legal form. In a similar sense, the OECD in the Report Traitement National des Enterprises sous Controle Étranger, Paris, 1993, pp. 22-23, adds that there can be established differences between the different economic activity sectors.

90 The OECD in the Report Traitement National des Enterprises sous Côntrole Étranger, op. cit. n. 89 at p. 48 , has underlined that the existence or non-existence of discrimination should not be determined in light of the obstructing effect of the foreign investment, since to value this circumstance objectively is, on occasions, extremely complex. See also K. Vogel, Double Taxation Conventions, op. cit. n. 89 at p. 1147

91 OECD, Traitement National des Enterprises sous Controle Étranger, op. cit. n. 89 at p. 31 et seq. See also the OECD Declaration des Decissions de l'OCDE sur l investessement et les enterprises multinationales, Paris, 1992, p. 25 ff. 
object of ulterior precision's on the part of the OECD considering that 'on the contrary, the issue of the national treatment would be of application if, in the same circumstances, excessive or unjustified obligations could be estimated in relation to the treatment reserved for the national companies by contrast to those under foreign control'.

Therefore nothing prevents the application of this principle to the anti-thin capitalisation procedures. In the Spanish thin capitalisation norm the concurrence of these conditions can be estimated, insofar as a company resident in Spain under foreign control is subject to more aggressive fiscal rules than an uncontrolled resident corporation under the same circumstances. This means that the application of the norm comes not so much from the loans accomplished by non-residents, but from accomplishing them with those persons when they are under common control.

Also, the presence of an unjustified difference in dealing has to be found by paying attention to two factors. First, the fiscal evasion risk can also be produced, though in minor measure, at the internal level. Furthermore, the possibilities for evasion to take place are virtually the same when these operations are carried out between linked resident corporations as when they are carried out between a resident corporation and a permanent establishment of a non-resident company (linked) located in Spain. Secondly, the thin capitalisation norm is not limited to establishing other test requirements stricter than those applicable to transactions between residents (something which would be justified). It establishes a legal fiction of automatic application without the possibility for the taxpayer to test to the contrary.

This is something which can be considered excessive and disproportionate for the fulfilment of the task that the norm sets and, therefore, constitutes an infringement of the nondiscrimination principle guaranteed by the DTCs. Nevertheless, the Project of New Corporation Income Tax Law, as was previously cited, could solve this problem if the Spanish Tax Administration would make the conditions for allowing the taxpayer to demonstrate the fulfilment of the arm's length principle more flexible.

It is necessary to estimate an evident symmetry between this doctrine and the principles that the Committee of Fiscal Matters OECD established in relation to the compatibility of the thin capitalisation procedures with art. 24.4 MC OECD. In this case, also, the proportionality and flexibility of the legal instruments that determined the application of the regulation against tax evasion were demanded, placing special emphasis on the indispensable guarantee on the effective defence of the taxpayer in order to prove the existence of an arm's length situation. It is also true that the OECD Fiscal Committee has established the preference of the principles taken up in para. 4 with respect to those of para. 5, art. 24 MC OECD 1992 on thin capitalisation. ${ }^{92}$ Therefore, it has established that the compatibility of a national thin capitalisation norm with para. 4, art. $24 \mathrm{MC}$ OECD would become equally accordant with para. 5 of the same clause. Nevertheless, where a DTC did not take up para. 4 but did take up para. 5, art. 24 MC OECD $(1992,1995)$, the non-application of the national anti-thin capitalisation norm could be invoked when such prohibition was not observed. ${ }^{93}$

This same principle has independent and stronger application in the Community framework by virtue of art. 221 EC Treaty. The EC Court of Justice declared in the Daily Mail judgment ${ }^{94}$ that the Treaty guarantees national treatment with regard to the financial participation of a national of a Member State in (national) corporations of another Member State (art. 58 EC Treaty). It should be noted that in relation to this Community prohibition, the rules and justifications taken up in the DTCs do not operate, so (that) the Community taxpayer could invoke EC law by itself.

In other words, applying this doctrine to the Spanish thin capitalisation established by Law $61 / 78$ as well as by the Project of Corporation Income Tax Law, there is a violation of a double or triple prohibition, the consequence of which will be its non-application where the DTCs take up the clauses of paras. 3, 4 and 5 MC OECD. ${ }^{95}$

"2. Number 58 of the commentaries on para. $5^{\circ}$ of art. 24 MC OECD 1992.

93 By contrast, the Spanish Tax Administration (DGT) in the resolution of 22 November 1994 (published in Crónica Tributaria, 1995/74, pp. 185-186) asserts that the Spanish thin capitalisation (art. 16.9 Law 61778) is compatible with the DTCs.

,94 ECJ, 27 September 1988, Case 81/87, ECR, p. I-5483, point 17; 25 July 1991, Case 221/89, Factortame, ECR-3905, points 31-33.

95 These principles are not applicable to a series of DTCs ratified by Spain. The DTC with Australia totally omits art. $24 \mathrm{MC}$ OECD; the DTC with the USSR does not take up paras. $4^{\circ}$ and $5^{\circ}$ of art. $24 \mathrm{MC}$ OECD; and, finally, the DTC with Argentina (no. 8 Protocol), Ireland (no. 6 Protocol), Mexico (no. 5 Protocol) and Portugal (no. 4 Protocol) establish clauses sanctioning the application of the Spanish thin capitalisation legislation without invoking the nondiscrimination principle to request its exclusion. 


\section{Incidence of arts. 10 and 23 MC OECD 1992}

Another condition that the OECD Committee of Fiscal Matters has incorporated in the Model Convention in order to apply thin capitalisation procedures in the DTCs' framework is that the lendor should share the risks taken by the borrower company. In effect, this requirement (noted in the report on 'The Sous-Capitalisation' ${ }^{96}$ ), has been introduced by the Fiscal Committee through the many commentaries made to the Model Convention.

On the one hand, with the analysis of art. 10.3 MC OECD 1992 it has declared in its commentaries $^{97}$ that:

'Article 10 deals not only with dividends as such, but also with interest on loans insofar as the lender effectively shares the risks run by the company, i.e. when repayment depends largely on the success or otherwise of the enterprise's business. Articles 10 and 11 do not therefore prevent the treatment of this type of interest as dividends under the national rules on thin capitalisation applied in the borrower's country.'

On the other hand, with the motive of preserving the internal coherence of the DTCs coordinating the consequences of the thin capitalisation reassessment with the double taxation relief, the OECD Fiscal Committee again insists on the necessity of the aforementioned requirement. Thus, in no. 67 of the commentaries on art. 23A and $\mathrm{B}$ it establishes that:

'In the so-called thin capitalisation situations, the Model Convention allows the State of the borrower company, under certain conditions, to treat an interest payment as a distribution of dividends in accordance with its domestic legislation; the essential condition is that the contributor of the loan should effectively share the risks run by the borrower company.'

At the same time, the Committee of Fiscal Matters has not only marked the need for the concurrence of this requirement, but it has fulfilled some of the criteria in the light of which the presence of the risk can be estimated. Thus, in the commentaries on art. 10.3 MC OECD $1992^{98}$ it has declared that 'the question whether the contributor of the loan shares the risks run by the enterprise must be determinate in each individual case in light of all the circumstances, as, for example the following:

- the loan outweighs very heavily any other contribution to the enterprise's capital (or was taken out to replace a substantial proportion of capital which has been lost) and is substantially unmatched by redeemable assets;

- the creditor will share in any profits of the company;

- repayment of the loan is subordinate to claims of other creditors or to the payment of dividends;

- the level or payment of interest would depend on the profits of the company;

- the loan contract contains no fixed provisions for repayment by a definite date.'

As such the presence of this requirement constitutes an indispensable element in that the application of anti-thin capitalisation operates in the framework of a DTC that follows the MC OECD faithfully.

In reference to the position of the Spanish thin capitalisation norm on this requirement of the DTCs, in Law 61/78 as well as in the Project, no element establishes a differentiation between loans which carry risks for the non-resident lender and loans which in this circumstance do not carry such risks. In this sense, the reassessments of interest as dividends that eventually could take place in the framework of relations covered by DTCs that follow the MC OECD, would only be accomplished by computing those loans with linked non-residents in which the concurrence of the effective participation of the lender in the risks taken by the borrower company is verified. This should be examined in light of all the circumstances by applying identical or similar criteria to those exposed by the OECD Fiscal Committee. This means that in the approved DTCs, without changing art. 10.3 MC OECD, ${ }^{99}$ (the application of the Spanish

96 OECD, 'La Sous-Capitalisation', op. cit. n. 15 at paras. 57 and 58.

97 Number 25 of the commentaries on art. 10.3 MC OECD 1992.

98 Number 25 in fine of the commentaries on art. 10.3 MC OECD 1992

99 The next Spanish DTCs follow art. 10.3 MC OECD: with Germany (art. 10.4), with Austria (art. 10.3), with Belgium (art. 10.4), with Brazil (art. 10.4), with Canada (art. 10.3), with Czechoslovakia (art. 10.5), with Denmark (art. 10.3), with Finland (art. 10.3), with France (art. 10.5), with Hungary (art. 10.3), with Italy (art. 10.3), with Japan (art. 10.3), with Luxembourg (art. 10.3), with Morocco (art. 10.4), with Norway (art. 10.3), with Poland (art. 10.3), with Portugal (1968 and 1993) (art. 10.3), with the UK (art. 10.4 and 6), with Romania (art. 10.3), with Sweden (art. 10.3), with Switzerland (art. 10.3), with Tunisia (art. 10.5), with the USA (art. 10.3), with China (art. 10.3), with Ecuador (art. 10.5), with South Korea (art. 10.3), with India (art. 10.3), with the Philippines (art. 10.3), with Ireland (art. 10.6) and with Argentina (art. 10.3). 
thin capitalisation rule) the concurrence of this condition (lender risk participation) is required. ${ }^{100}$ When this condition is not present we understand that the thin capitalisation will only have unilateral effects, i.e. the excessive interest could be treated as dividends for the borrower's taxable income but this assessment could not affect the non-resident lender. This different treatment will frequently give rise to international economic double taxation. One way to solve these problems could be to apply the Arbitration Convention. There are a minority of Spanish DTCs ${ }^{101}$ that do not follow art. 10.3 MC OECD allowing that these excessive interests be treated as 'dividends'. Also some other DTCs ${ }^{102}$ established a disposition to surpass this obstacle.

Another limitation that can be derived from the MC OECD for the application of the Spanish thin capitalisation norm is when the operability of this in the framework of the DTCs is limited to the paid interest; therefore in relation to interest accrued but not effectively paid, the effects of this regulation cannot be applied. This idea is detached not only from the tenor of para. 1 of arts. 10 and 11 MC OECD 1992, but also from the commentaries themselves of the OECD Fiscal Committee in relation to the rules effected by the thin capitalisation. ${ }^{103}$ The topic is not some trifling or academic matter, since, in current legislation, their application to this type of revenue due, but not paid, is discussed. ${ }^{104}$ The Project of Corporation Income Tax Law ${ }^{105}$ that is currently being enacted by the Spanish Parliament, takes up the application to the accrued interest in art. 20.

It is important to emphasise that, in order to solve the multiple conflicts that can emerge in this area, the mutual agreement procedure provided by art. $25 \mathrm{MC} \mathrm{OECD}^{106}$ has been specifically arbitrated. The mutual agreement procedure established in the cited rule can channel the resolution of these and other problems related to the application of national thin capitalisation rules in the scope of DTCs, though the setting-up of an arbitral procedure might have been preferable (Convention 90/436).

B. Analysis of the Spanish Thin Capitalisation Rule in light of the NonDISCRIMINATION PRINCIPLE BY REASON OF NATIONALITY AS ESTABLISHED BY EC LAW

\section{On the relevancy of the issue at Community level}

Some people have maintained that the application of the Spanish anti-thin capitalisation rule does not cause any discrimination problem at Community level when the lenders are residents of a Member State of the European Union. ${ }^{107}$ It is argued that the issue is not relevant because Spanish fiscal legislation establishes that interest paid to Community residents (non-residents of Spain) are exempt from tax at source, the same as the dividends that a Spanish subsidiary distributes to its Community parent company when the conditions of Directive 90/435/EEC, 23 July 1990, are fulfilled.

Therefore, on the basis of a hypothetical taxation neutrality of the thin capitalisation norm the irrelevancy of the issue is justified and, consequently, so is the non-existence of discrimination.

Our position is very far from this inasmuch as we disagree on the intended neutrality of the application of the Spanish thin capitalisation norm to non-resident taxpayers.

In effect, the reassessment and fiscal treatment of the excessive interest on dividends causes important legal tax consequences (for the borrower corporation as well as for the lender), that the contingent application of Directive 90/435/EEC does not solve.

This Community arrangement is applied neither to all types of corporations, nor to all those supposedly covered by the Directive inasmuch as the parent company, endowed with a given

${ }^{100}$ Article 11.6 of the Spain/UK DTC denies the possibility of this treatment even when the lender risk participation condition occurs, except when more than 50 per cent of the voting rights of the lender are owned, directly or indirectly, by residents of the borrower State of residence.

101 DTCs with the Netherlands (art. 10.5), with the USSR (art. 8.3) and with Australia (art. 10.3).

112 See Protocols 5 and 8 of the DTCs with Mexico and Argentina, respectively. The Protocols with Ireland and Portugal do not surpass this obstacle insofar as they only except the application of the non-discrimination principle on thin capitalisation.

${ }^{103}$ See commentaries nos. 7 and 8 on art. 10, nos. 5, 32, 35 on art. 11, and no. 67 on art. 23 MC OECD 1992.

104 C. Palao Taboada, 'La Subcapitalización y los CDI', op. cit. n. 2 at p. 91, studied the question whether the Spanish regulation referred to the paid interest or the accrued interest, considering that 'the countable orthodoxy carries us to incline towards this last alternative surpassing the laterality of law'. For an alternate opinion see Rey \& Collado 'Aspectos fiscales de la subcapitalización', op. cit. n. 2 at p. 91.

105 Project of Law of Corporation Taxation (BOF Cortes Generales, no. 106 A-1, of 24 March 1995).

1106 Number 34 of the commentaries on art. 25 MC OECD 1992.

107 In this sense I cannot agree with S. Raventos Calvo, 'The Treaty shopping in the last DTC signed by Spain', op. cit. n. 78 at pp. $74-75$.

intertax

$1996 / 8-9 \quad 299$ 
legal form, must receive the 'dividend' in the capacity of shareholder as cited previously. Furthermore, where a permanent establishment of a Community corporation located in a third Community country is the one which might have organised the loan and fulfilled the remaining requirements for the application of the Directive, the dividends would generally suffer economic double taxation - a rather non-neutral phenomenon which obstructs Community freedoms.

On the other hand, the great legal insecurity that the non-existence of a binding assessment of the 'dividends' causes in the parent company State of residence has been underlined previously, in so far as the Directive does not provide for these cases. Therefore, the most frequent thing would be that, in spite of the application of the Directive by the source State (not withholding $\operatorname{tax}$ ), the State of residence of the recipient (parent company) of the 'dividends' considers and treats these as interest, resulting in economic double taxation.

The affirmations that have just been exposed certainly demonstrate the important consequences that the application of the Spanish thin capitalisation rule has for all the parties implicated in these situations of indebtedness. Nevertheless, the existence of a fiscal discrimination contradictory to the Treaty of Rome cannot be taken from the simple consideration of the neutrality of the application of this norm, but, on the contrary, the concurrence of this must be accomplished in the light of a series of factors that will subsequently be examined.

2. On the existence of a violation of the Community prohibition of non-discrimination by reason of nationality on the part of the Spanish thin capitalisation rule

a. Previous approximation to the configuration of the Community prohibition of the discriminations by reason of nationality in fiscal matters

Community law, based on legal principles which have been consolidated in most western countries, ${ }^{108}$ has established the prohibition of all discrimination by reason of nationality without a clear objective basis.

This prohibition is established in art. 6 EC Treaty ${ }^{109}$ and, with specific character in numerous rules of the Treaty, i.e. in art. 48.2 (freedom of movement of workers), arts. 52 and 58 (freedom of establishment), arts. 59 and 65 (freedom of provision services) and art. 67 (freedom of movement capital). ${ }^{110}$

This main Community principle has been substantially configured and developed through the jurisprudence of the ECJ. There is reiterated jurisprudence asserting that 'the rules of treatment equality prohibit, not only the founded ostensible discriminations on nationality, or headquarters with respect to corporations, but also all hidden or underhand forms of discrimination, that, by application of other distinctive criteria, lead in effect to the same result'.111

Certainly, this definition of the non-discrimination principle by reason of nationality at Community level, as opposed to what happens in relation to art. 24.1 MC OECD, permits the application of this postulate in relation to the possible differences of fiscal treatment which the internal legislations of the Member States establish between the persons (physical or legal) resident and non-resident. The different treatment that exists between the persons subject to tax on their world-wide income and on the source income criteria does not entail (in abstract) a fiscal discrimination forbidden by the Treaty. On the contrary, this distinction is the one which not only prevails in most of the tax systems but is also confirmed by the Committee of Fiscal

108 Note that, by virtue of arts. 13.1 and 14 of the Spanish Constitution, foreigners are equally covered by the principle of non-discrimination. See the jurisprudence of the Spanish Constitutional Court of 23 November 1984 (BJC 44, p. 1400 ) and of 30 September 1985 (BJC 54/55, p. 1141).

109 Note that the operability of art. 6 EC Treaty is limited. The EC Court of Justice has declared that art. 6 can only be applied to situations governed by EC law for those which the Treaty does not provide specific precepts against the discrimination. (ECJ, 30 May 1989, Commission/Greece, Case 305/87, ECR, p. I-1461; 12 April 1994, Halliburton Services, Case 1/93, ECR, p. I-1137). See K. Van Raad, Non-Discrimination in International Tax Law (Kluwer, Deventer, 1986), pp. 39 et seq.

${ }^{110}$ In relation to the EC non-discrimination principle in direct taxation see P. Bentley, 'Tax Obstacles to Cross-border business' in Corporate Law - The European Dimension (Butterworths, London, 1991), p. 196 et seq.; P. Kaverlaars, 'Direct Taxation and some Basic Principles in EC Law', Intertax, 1993/12, p. 597 et seq.; B. Knobbe-Keuk, 'Restrictions on the fundamental freedoms enshrined in the EC Treaty Ban and justification', op. cit., p. 74 et seq.; B. Terra \& P.Wattel, European Tax Law op. cit. n. 71 at p. 21 et seq.; R.A. Sommerhalder, 'Differences in tax treatment between a resident and non-resident individual in conflict with EEC Treaty', IBFD, March 1993, p. 101 et seq.; K. Van Raad, 'The meaning of non-discrimination' in Taxation of Cross-Border Income, Harmonization, and Tax Neutrality under European Community Law (Kluwer, Deventer, 1994), p. 43 et seq.; Y. Kergall, 'Using the Treaty of Maastricht to combat discriminatory practices in 1995. Examples in France', Intertax, 1995/4, p. 174 et seq.

11 ECJ, 12 February 1974, Sotgiu, Case 152/73, ECR, p. I-153 et seq.; 29 October 1980, Boussac, Case 22/80, ECR, p. I3427 et seq.; 13 July 1993, Commerzbank, Case 330/91, ECR, p. I-4017 et seq.; 12 April 1994, Halliburton Services, Case 1/93, ECR, p. I-1137 et seq. 
Matters OECD and the United Nations Fiscal Committee. ${ }^{12}$ Also, the same Community legislator employs these same criteria for direct taxation, ${ }^{113}$ as well as for indirect taxation. ${ }^{114}$

One thing to note is the generic validity (in abstract) of the heterogeneous fiscal rules anticipated for residents and non-residents. Another is the acceptance in any event of all the differences of fiscal treatment that, being sheltered on the generic validity of these criteria, are established in given situations. It is precisely in this area where the jurisprudence of the ECJ has had an impact, which indicates the existence of unjustified tax discrimination.

In most circumstances one of the key factors used to estimate the existence or non-existence of discrimination as forbidden by Community law comes from the analysis of two interlinked problems: in the case outlined, if the residents and non-residents are in the same circumstances and if there is a justifiable objective element that excludes its anti-juridical character. At the same time, it is important to point out, in the field of direct taxation, the obstructing character the difference of treatment has to the application of the EC prohibition. The ECJ, perhaps in order to avoid unavoidable subjectivism in valuing this factor, generally omits the analysis of this circumstance, thus objectifying the examination of the issue. However, in some cases (Halliburton, Schumacker \& Wielockx) the obstructing character of the discrimination played an important role.

In relation to the first of these problems, the Community Court of Luxembourg has been examining the presence of a comparable situation between resident and non-resident taxpayers not paying attention to the different extent of their tax liability. The ECJ pays special attention to this discriminatory norm and this is part of the reason for placing the non-resident in an unfavourable position with respect to the resident. ${ }^{115}$

Thus, in the leading case of the avoir fiscal ${ }^{116}$ the issue of admissibility of discriminations based on residence is outlined. The ECJ declares prima facie that a distinction on the basis of the residence of a corporation or according to the residence of a physical person cannot be excluded absolutely. Under certain conditions fiscal discriminations can be justified. However, in this case French tax legislation was excluding the permanent establishments of certain kinds of nonresident companies (insurance) located in France, from the application of a deduction of double taxation on dividends, while this same benefit was enjoyed by the resident corporation in the same activity sector. In this case the national tax legislation, in general terms, was granting a similar tax treatment to the residents and to the permanent establishments (non-resident), so the Community Court understood that a comparable situation existed and that the aforementioned discrimination was an infringement of Community law (art. 52 EC Treaty).

In the Biehl ${ }^{117}$ case the ECJ also approaches the validity of the fiscal distinction between residents and non-residents. Here the examination of this issue is not so much in analysis of the justification of the different extension of their contributing obligation, as in questioning if these criteria, and the different fiscal rules that make it up, serve to base objectively an internal norm of a Member State that was demanding to exhibit the resident condition of said company in order to obtain the excessive withholdings refund. In this matter the EC Court of Luxembourg also understood that the resident and non-resident taxpayers were in a comparable situation and, therefore, they should enjoy the same rights in the withholdings refund matter.

The subject of residence as a fiscal subordination criterion for tax returns was raised again in the judgment of 26 January $1993 .{ }^{118}$ In this case a German national, who was a resident of the Netherlands, obtained most of his income in Germany where he was a non-resident. The taxpayer understood that the reservation of certain deductions (the splitting tariff system) for the resident taxpayers of Germany was contrary to EC law. The ECJ understood that there was no comparable situation between said taxpayers and, therefore, the German tax rule was compatible with the Treaty. It is appropriate to emphasise that the good judgment of the ECJ was probably negatively influenced by the fact that the claimant was a German national (internal situation). This idea is deduced from clause 17 inasmuch as the ECJ declared that in such circumstances art. 52 EC Treaty does not prevent a Member State from taxing nationals who exercise their professional activities in its territory and who receive the entire or bulk of their revenue there, with a heavier fiscal charge when they do not reside in the Member State than when they do.

\footnotetext{
112 See arts. 1 and 4 of the MC OECD 1992 and MC UN (1980).

113 See, for example, arts. 1, 4 and 5 of Directive 90/435/EEC, of 23 July 1990, as well as art. 3 of Directive 90/434/EEC, of 23 July 1990.

114 See VAT Directives 77/388/EEC and 92/212/EEC.

115 See B. Knobbe-Keuk, 'Restrictions on the fundamental freedoms enshrined in the EC Treaty Ban and justification', op. cit., p. 77 et seq.

116 ECJ, 28 January 1986, Commission/France, Case 270/83, ECR, p. I-285 et seq. See the interesting commentaries of R. Falcon and Tella in relation to this decision (Revista de Instituciones Europeas, vol. 13, no. 12/86).

117 ECJ, 8 May 1990, Case 175/88, ECR, p. I-1779 et seq

118 ECJ, 26 January 1993, Case 112/91, ECR, p. I-419 et seq.
} 
The Commerzbank judgment ${ }^{119}$ examines the subject already mentioned in the cases of Just and $B i e h l^{120}$ with the motive of the denial of the tax income refund to the non-resident (a permanent establishment of a German corporation in the UK) under the same conditions as applied to the residents of a Member State. The ECJ understood that a comparable situation existed comparing the norm between residents and non-residents (the permanent establishment). In particular, it is suitable to point out the line adopted by the Court, insofar as it declares that in this case, the different extension of the tax obligation that results in the residents/nonresidents rules does not place anyone in a different position in relation to the effects of the tax income refund. On the contrary, they participate in a comparable situation. Consequently, the Court found against the inadmissibility of the British legislation that excluded the non-resident from the said benefit.

Finally, the EC Court of Luxembourg recently pronounced in the Roland Schumacker ${ }^{121}$ and G.H.E.J. Wielockx ${ }^{122}$ cases, with surprising clarity and consistency, the admissibility of different treatment in reference to the residence of the Community taxpayer. In the opinion of the Court, the different fiscal rules established in reference to the condition of resident/non-resident of the Community taxpayers is justified when all or most of the income is obtained in the country of residence. In this case, it is admissible and, therefore, not discriminatory, for the source taxation to exclude some deductions, as those relating to the personal or family situation of the taxpayer. More rigorous rules are being applied that will be compensated in the country of residence, where such a situation will be taken into account. In these cases, 'a comparable situation' does not exist, therefore, the heterogeneity of the tax obligation is admissible. By contrast, where a non-resident obtains all or most of their income in the source country there is a comparable situation, so an objective situation that could justify the difference in treatment does not exist (point $37 \mathrm{R}$. Schumacker). In fact, in cases where the non-resident obtains all or most of their revenue in the source State, a comparable situation exists with the residents of the aforementioned State, who cannot be deprived of the same deductions and advantages recognised in the source State by the residents. ${ }^{123}$

In reference now to the second issue, i.e. the possibility of justifying or objectifying a difference of fiscal treatment excluded from the Community prohibition, it is appropriate to emphasise the strict posture adopted here by the ECJ, ${ }^{124}$ as well as the relevancy of this issue for the analysis of the compatibility of the Spanish thin capitalisation rule with EC law.

It is reiterated jurisprudence to refuse the justification of discrimination as a result of a lack of some harmonisation on this matter, even in an area, like direct taxation, which is not included in the field of Community competence. ${ }^{125}$

Neither has the invocation of a future tax collection loss been sufficiently understood to base a national norm that establishes a treatment difference. ${ }^{126}$ Nevertheless, EC law as well as EC

119 ECJ, 13 July 1993, Case 1/93, ECR, p. I-1139 et seq. See the commentary of J.G. Goldworth in Tax Notes International, vol. 9, no. 7, 1994, p. 505.

120 ECJ, 27 February 1980, Case 68/79, ECR, p. I-501 et seq.; 8 May 1990, Case 175/88, ECR, p. I-177 et seq. See also the concordant jurisprudence Rewe and Comet, of 16 December 1976 (Cases 33 and 45/76, ECR, pp. I-1989 and 2043, respectively).

121 ECJ, 14 February 1995, Case 279/93, p. I-225 et seq. See the comments of B. Knobbe-Keuk, 'ECJ Bans discrimination against non-residents', Intertax, 1995/5, p. 234 et seq.; O. Thömmes, 'European Court of Justice decides Schumacker case in favour of non-resident taxpayers', Intertax, 1995/5, p. 264 et seq.; D. Witteveen, 'Taxation of non-residents in the EU: tax equality or patchwork quilt', EC Tax Review, 1995/3, p. 122 et seq.

122 ECJ, 11 August 1995, Wielockx, Case 80/94, Semaine de la activité de la Cour, no. 22/95, pp. 7-9.

123 It is necessary to emphasise the Commission has calculated that a non-resident which has obtained 75 per cent of its world-wide income in the source State, is in a comparable situation to that of residents of the source State (Recommendation 94/79/EEC (EC Journal, L.39/22, 10 February 1994, p. 22 et seq.)). See O. Thömmes, 'EC Commission starts new initiative on taxation of non-residents', Intertax, 1994/9, p. 182 et seq.; I. Merino Jara published in Jurisprudencia Tributaria Aranzadi, 1993, vol. III, p. 1304 et seq.; L. Docavo Alberti, 'La armonización de la tributación de los no residentes en la UE', Impuestos, 1995/2; as well as the work of the author published in Quincena Fiscal Aranzadi, 1994/11, p. 39 et seq. However, German law (Grenzpendlergesetz, of 24 June 1994, BStB1. 1994 p. I-1395) established a different percentage (90 per cent). The same solution was adopted by the Ausfuhrungsgesetz Grenzganger Niederlande, 21 October 1980 in order for the application of the tax treaty between Germany and the Netherlands (1959, Protocol of 1980).

124 The European Court of Justice places the onus on the national authorities to show the validity of the exception to a fundamental principle of the Treaty. (EC Court of Justice, 30 November 1983, Leendert van Bennekom, Case 227/82, ECR, p. I-3883.)

125 ECJ, 28 January 1986, Commission/France, Case 279/83, ECR, p. I-285 et seq.; 14 February 1995, R. Schumacker, Case 279/93, $Q F, 1995 / 4$, p. 48 et seq. (particularly point 21 ).

126 See B. Knobbe-keuk, 'Restrictions on the fundamental freedoms enshrined in the EC Treaty - Ban and Justification', op. cit., p. 79 et seq. 
jurisprudence permits the establishment of difference of treatment in tax matters where there exists a legitimate interest of a Member State in order to safeguard existing fiscal rights. ${ }^{127}$

In this sense, EC law, aside from the exceptions that can be derived from this principle for motives of public order, safety and health care, ${ }^{128}$ (the Treaty) has specifically established in art. 73D.1, in relation to freedom of movement of capital, the right of the Member States to:

(a) apply the relevant arrangements of its fiscal law that distinguish between contributors whose situation is different with respect to its place of residence or with respect to the places where their capital is invested;

(b) adopt the necessary measures to prevent breaches in the law and national regulations, in particular in fiscal matters and of prudential supervision of financial entities. To establish procedures of declarations of movement of capital for the purpose of administrative information or statistics or to take the justifiable steps for reasons of public order or public safety. ${ }^{129}$

Nevertheless, para. 3 of the same rule establishes that these should not constitute either a means of arbitrational discrimination, nor a hidden restriction of the free movement of capital and payments. ${ }^{130}$

Community jurisprudence has also understood there to be some foundation in the restrictions on Community freedoms on the basis of a legitimate interest of a Member State in order to prevent prejudicial acts on its existing tax rights on a given taxable matter. In the Daily Mail ${ }^{131}$ case the ECJ prevented the fiscal migration of an English corporation to the Netherlands. It understood that arts. 52 and 58 of the Treaty should be interpreted in the sense that, in the current State of Community Law, they do not confer to a corporation constituted according to the legislation of a Member State and which has its company domicile in this country, the right to move their headquarters to another Member State and to preserve at the same time the condition of the company of the Member State under whose legislation it was incorporated (point 24). The argument formally declared by the court was based on the lack of Community harmonisation on recognition of nationality of the legal entity. However, the basis of the position of the court was the acceptance of a restriction of a Community freedom when a legitimate interest for this was present. That is, in this case the protection of the existing tax rights of the British Exchequer on the capital gains generated in the past by the Daily Mail corporation. ${ }^{132}$

In this same line seems to be found the controversial, ${ }^{133}$ and today perhaps phased out, ${ }^{134}$ jurisprudence emanating from the cases of H.M. Bachmann ${ }^{135}$ and Commission/Belgium. ${ }^{136}$ In these cases the ECJ considered that the difference in fiscal treatment, i.e. the non-deductibility in the income tax IRPF of the premiums of insurance contracted by the resident workers of a country, based on the condition of being a non-resident of the Community insurer, was justified in the coherence of the fiscal system, whose concretion corresponds to each

127 See infra the Daily Mail and H.M. Bachmann cases.

${ }_{128}$ Articles 48.3, 56.1 and 73 D.1.b) EC Treaty. See the jurisprudence of the European Court of Justice in the decisions of 3 December 1974, Van Binsbergen, Case 33/74, ECR, p. I-1299 et seq.; 7 January 1979, Knoors, Case 115/78, ECR, p. I-399; 20 February 1979, Cassis de Dijon, Case 120/79, ECR, p. I-649.

${ }_{129}$ See Directive 88/361/EEC, of 24 July 1988 (EC Journal, no. L 178, of 8 July).

${ }^{130}$ See A.P. Dourado, 'Free Movement of Capital and Capital Income Taxation within the European Union', EC Tax Review, 1994/4, p. 179 et seq.; G. de Bont, 'Taxation and free movement of capital and payments', EC Tax Review, $1995 / 3$, p. 142 et seq

131 ECJ, 27 September 1988, Case 81/87, ECR, p. I-5483 et seq. See D. Berlin, 'Trends in jurisprudence of the Court of Justice of the EC', EC Tax Review, 1992/2, p. 91 et seq. In a previous case (decision of the avoir fiscal of 28 January 1986) the European Court of Justice considered that the risks of tax evasion cannot justify national restrictions of a fundamental freedom of the Treaty (art. 52). Also, the EC Court accepted that restrictions on fundamental freedoms were justified on 'general interest' reasons: (a) dispositions in order to avoid abuses of law (EC Court of Justice, 14 December 1989, Jaderow, Case 216/87, ECR, p. I-4509; 21 June 1988, Lair, Case 39/86, ECR, p. I-3161; 3 February 1993, Veronica, Case 148/91, ECR, p. I-513); (b) antifraud provisions (ECJ, 7 February 1979, Knoors, Case 115/78, ECR, p. I-399); (c) general interest protection (organisation rules, control, deontology, liability, consumer protection, justice, public health) (ECJ, 3 December 1974, Van Binsbergen, ECR, p. I-1299; 26 February 1991 , Commission/Greece, Case 189/89, ECR, p. I-727; 25 July 1991, Säger, Case 76/90, ECR, p. I-4239; 8 April 1992, Commission/Germany, Case 62/90, ECR, p. I-2601; 20 May 1992, Ramrath, Case 106/91, ECR, p. I-3351; 9 August 1994, Vander, ECR, p. I-3803).

132 See the conclusions of the General Lawyer Sr. Darmon (point 15).

133 B. Knobbe-Keuk, 'Restrictions on the fundamental freedoms enshrined on the EC Treaty - Ban and justification', op. cit., p. 79 et seq., understands that the insurer and the assured must not reside in the same country to guarantee 'the coherence of the fiscal system'. See art. 24.4 MC OECD and the Wielockx judgment (of 11 August 1995, Case 80/ 94, Semaine no. 22/95, pp. 7-9).

134 See the decision of the European Court of Justice of 11 August 1995, Wielockx, Case 80/94, Semaine de l'activité de la Cour, no. 22/95, pp. 7-9.

135 ECJ, 28 January 1992, Case 204/90, ECR, p. I-249 et seq.

136 ECJ, 28 January 1992, Case 300/90, ECR, p. I-305 et seq. 
State. This 'coherence' requires that said State is obliged to accept the deduction of the life insurance premiums paid in another Member State and could receive the tax on the quantities owed by the insurers. This jurisprudence in some way signifies the admission of restrictions on the right of non-discrimination where reasons exist based on tax collection or fiscal policy by a Member State. The latest ECJ jurisprudence has changed this point of view. The Schumacker and Wielockx cases strengthen the taxpayer's non-discrimination right, inasmuch as this principle prevails over other tax policy reasons. ${ }^{137}$

It is also very important for the examination of Community compatibility with the Spanish thin capitalisation norm, to emphasise how the EC Court of Luxembourg, especially in recent decades, demands additional requirements in order to understand that the measure is compatible with EC law. At present it is not sufficient that the purpose or the ratio legis of the national norm be sheltered by the objectives, task, principles or, even, by Community regulation. Rather, the way of executing by the national legislator of this authorisation, either explicitly or implicitly must be equally accordant with the rest of the requirements imposed by EC law. In this sense, the key idea with which the EC Court of Luxembourg operates in order to admit the validity of a restriction to a fundamental Community right, is that the national measures are necessary in order to protect a legitimate interest of the Member State, insofar as the exceptions to such fundamental freedoms cannot go further than what is necessary to reach the objectives that justify the cited exception. ${ }^{138}$

Three additional conditions have been presented that should be gathered in the national norm in order to be justified and compatible with the Treaty. First, the concurrence of the principle of proportionality must be estimated in the measure inasmuch as its absence, according to the ECJ, converts it to arbitrational discrimination. ${ }^{139}$ Secondly, the EC Court of Luxembourg has considered that trying to shelter a national measure that establishes a discrimination in a legitimate cause such as the prevention of fraud is improper and unacceptable where there are other ways of reaching the same target without incurring such difference of treatment. ${ }^{140}$ Thirdly, the jurisprudence of the 'custodian of the Community order' has also pointed out that even the national procedures that establish treatment differences in execution of authorisations or Community mandates should be carried out in such a way that they will cause the smallest possible obstacle for Community principles and freedoms, under penalty of being contradictory to the Treaty. ${ }^{141}$

Finally, it only remains to point out that the violation of the Community prohibition of nondiscrimination by reason of nationality constitutes a frontal breach of the Treaty of Rome. And, since this principle comes from the direct effect, the discrimination rule must not only be inapplicable, but also eradicated from the domestic law in order to comply with the unconditional commitment legally assumed by the Member States (art. 5 EC Treaty). ${ }^{142}$

\section{b. Study of the compatibility of the Spanish thin capitalisation arrangement with the EC non- discrimination principle}

The examination of the compatibility of the Spanish regulation on thin capitalisation with EC law must be carried out, on the basis of three factors: (a) the existence of treatment differences that bring about obstacles or restrictions contrary to the Treaty of Rome; (b) the concurrence of

${ }^{137}$ ECJ, 14 February 1995, Case 279/93, ECR, p. 225 et seq. (especially points 40-41); ECJ, 11 August 1995, Case 80/94, $Q F, 16 / 95$, p. 39 et seq. (especially points 23 and 27 ).

138 ECJ, 30 April 1986, Commission/France, Case 96/85, ECR, p. I-1475; 3 December 1974, Van Binsbergen, Case 33/74, ECR, p. I-1299; 7 January 1979, Knoors, Case 115/78, ECR, I-399; 20 February 1979, Cassis de Dijon, Case 120/78, ECR, p. I-649; 24 June 1986, Brugnoni, Case 157/85, ECR, p. I-2013.

139 ECJ, 7 December 1981, Nederlandse Marts Chapij, Case 272/80, ECR, p. I-3277 et seq.; 10 November 1982 , Rau, Case 261/81, ECR, p. I-3961 et seq.; 15 October 1982, Oosthecks, Case 286/81, ECR, p. I-4575 et seq.; 12 March 1987, Commission/Germany, ECR, pp. I-1227-1274; Affaire Coenen, Case 39/75, ECR, p. I-1556; 4 December 1989, Jaderow, Case 216/87, ECR, p. I-4509; 25 July 1991, Säger, Case 76/90, ECR, p. I-4239; 8 April 1992, Commission/ Germany, Case 62/90, ECR, p. I-2601; 2 August 1993, Commission/France, Case 276/91, ECR, p. I-4413.

${ }^{140}$ ECJ, 10 July 1986, Segers, Case 79/85, Recp. I-2375 et seq., particularly, points 16-17; 3 December 1974, Van Binsbergen, Case 33/74, ECR, p. I-1299; 14 December 1989, Jaderow, Case 216/87, ECR, p. I-4509; 30 April 1986 , Commission/France, Case 96/85, ECR, p. I-1475; 25 July 1991, Säger, Case 76/90, ECR, p. I-4239; 20 May 1992, Ramrath, Case 106/91, ECR, p. I-3351; 30 February 1993, Veronica, Case 148/91, ECR, p. I-513; 9 August 1994 , Vander, Case 43/93, ECR, p. I-3803.

141 ECJ, 22 July 1994, Deutsches Milch-Kontor, Case 496/94 ECR, p. I-2757 et seq., particularly points 52-54; 15 December 1976, Simmenthal, Case 35/76, ECR, p. I-1871; 13 July 1995, Case T-466/93, 467, 473, 473 and 477/93, O'Dwayer/Commission, Semainde de l'activité de la Cour, no. 21/95; 13 September 1995, TWD/Commission, Cases T244 and 486/93, Semaine no. 23/95.

142 ECJ, 4 April 1974, Commission/France, ECR, p. I-359 et seq.; 17 February 1970, Case 31/69, ECR, p. I-25 et seq.; 9 March 1978, Simmenthal, Recp. I-643 et seq.; 25 October 1979, Commission/Italy, ECR, p. I-3247 et seq.; 20 October 1981, Commission/Belgium, ECR, p. I-2393 et seq.; 15 October 1986, Commission/Italy, ECR, p. I-2495 et seq. 
a comparable situation between the resident and the non-resident; and (c) the appraisal of a justifying element of the discrimination contingent.

The existence of differences of direct and indirect dealing that affect the position of the taxpayers must be estimated. This gives origin to important obstacles to and restrictions on the effective exercise of Community freedoms which seriously distort the good operation of the interior market in the area in which the Spanish thin capitalisation rule operates.

As is known, the Spanish thin capitalisation norm is applied solely in relation to loans carried out between resident corporations of Spain and non-resident lenders, linked directly or indirectly with the corporation. Only where the lender is a non-resident of Spain is the thin capitalisation norm applied and the reassessment of the excessive interest as 'dividends' carried out.

Certainly, the operability of this norm affects the two parties involved in the loan. The 'dividends' will not be deductible against the taxable income of the Spanish borrower. At the same time, the recipient of the interest will generally suffer a fiscal increase due to the treatment of the excessive interest as 'dividends'. This will happen on most occasions, independent of the fiscal residence of the Community lender in a country with which Spain has ratified DTCs. This circumstance occurs because, generally, the dividends are subject at source to superior tax rates to those applicable to the interest by internal legislation as well as in the DTCs. Another determining factor of the greater fiscal charges on this revenue is the economic double taxation that will frequently fall on the interest reassessed as 'dividends'. As was previously explained, the State of residence of the recipient, on the basis of its independent and autonomous fiscal sovereignty, will not accept the reassessment carried out by the source State and then, will consider the revenues as interest without applying the measures for the suppression of the cited phenomenon.

It is true that the application of the DTCs and Directive 90/435/EEC may suppress these two increasing tax charge factors on the 'dividends' received by the Community non-resident. Nevertheless, the fiscal neutrality in the application of the Spanish thin capitalisation rule is the exception at present.

In relation to the DTCs, it has been observed that some very singular circumstances must be present in order for the national thin capitalisation rules to operate in this framework. Moreover, even in cases where the thin capitalisation norm is adapted to the principles established by the OECD Committee of Fiscal Matters, nothing fully guarantees the qualifying symmetry of the 'dividends' in the State of residence of the recipient, thus resulting in economic double taxation.

In connection with the efficiency of Directive 90/435/EEC, we have previously pointed out the problems that result from the contingent application in relation to the reassessed interest as 'dividends' based on national thin capitalisation procedures. Even where the objective and subjective conditioners that are required for concurrence with this norm, the more frequent occurrence would be that only the source State granted the fiscal treatment of 'dividends' to the reassessed revenues and then there would also be economic double taxation. ${ }^{143}$

On the other hand, the application of the Spanish thin capitalisation rule results in indirect discrimination to the Community lenders (non-residents of Spain). This happens insofar as this norm penalises the indebtedness of residents with non-residents, something that prima facie,

${ }^{143}$ At the same time, in the cases where it is a permanent establishment of an EC resident corporation located in a third Member State which might have carried out the loans, there will probably be residual economic double taxation as well. This happens because the measures adopted by the State of residence of the central office (parent company) would not generally suppress totally the effects of this phenomenon, even supposing the State of residence of the parent company accepted the qualification of 'dividends' in relation to the excessive interests. When the exemption method is used in said State, the interest reassessed as 'dividends' obtained by the permanent establishment would not be encumbered by the tax on the revenue of the State of residence of the parent company, but would sustain the corporation tax of the residence country of the subsidiary (the borrower) and the corporation tax of the location country of the permanent establishment. Therefore this measure would eliminate the international double taxation, but not the economic double taxation. Where the foreign tax credit method is applied, the same would happen where the tax of the parent company of the residence country on the 'dividends' would be lower than the sum of the taxes of the subsidiary residence country (borrower) and of the location of the permanent establishment on these same revenues.

Nevertheless, this phenomenon would be suppressed when the country of residence of the parent company operated, with the unlimited modality of the foreign tax credit method, or with an overall or per country limit that permitted the deduction of the sum of the cited taxes against the quota of the tax of the residence of said parent company. However, these last two hypotheses, apart from being infrequent, imply a distribution of the tax power between the involved States which is very difficult to accept. Perhaps the most suitable alternative in this sense would be to modify the subjective area of art. 2 of Directive 90/435/EEC so that the country of location of the permanent establishment would be obligated to suppress this phenomenon. See F.A. Garcia Prats, 'Application of the Parent company/Subsidiary Directive to Permanent Establishments?', European Taxation, June 1995, pp. 179-187. This solution was adopted recently by Austria through the national law that implements Directive 90/435/EEC (s. 21 no. 2 Corporation Income Tax Act 1988). See M. Jann, 'The implementation of direct and indirect tax Directives in Austrian Tax Law', op. cit. n. 67 at 1995/3, p. 144 
places the non-resident lender in a less favourable situation than the Spanish resident. This effect occurs even where, as in the case of the permanent establishment of a Community company located in Spain, there are hardly any differences in the manner of exercising the activity, or in its fiscal treatment.

In this sense, the doctrine of the EC Court of Luxembourg in the case of Halliburton Services ${ }^{144}$ does not offer any doubts as to what is referred to by the proscription of differences of indirect dealing. In this leading case the ECJ understood that the Dutch norm that was reserving the exemption of the transfer tax (ITPAJD) only in the case in which the beneficiary corporation of such exemption acquires the goods of a national corporation and refuses them on the rest of the occasions, constitutes an indirect discrimination by reason of nationality in contradiction to the Treaty. The payment of the transfer tax constitutes a load that worsens the conditions of sale of the good and, as such, impinges on the situation of the transmitting person placing him in a position less favourable in comparison to the national of the afore-mentioned State. $^{145}$

If we apply this doctrine, the difference in treatment approved by the thin capitalisation norm, up to the point in which justification can be found, could be understood to be contradictory to the Treaty insofar as it blocks the freedom of financial services. ${ }^{146}$

At the same time, the compatibility of the Spanish thin capitalisation norm with EC law could also be judged in light of the discriminations that originate as a result of the right of establishment guaranteed to all nationals of Community countries in equal conditions, as stated by arts. 52 through to 58 of the Treaty. This fundamental principle of the Treaty guarantees the nationals of Member States access to non-salaried activities and its exercise in the same conditions provided by the legislation of the other Member States for their own nationals (art. 52 EC Treaty). ${ }^{147}$ This means that the corporations incorporated according to the legislation of a Member State and whose business headquarters, central administration or activities centre is found in the EU, have the right to exercise their activity in the other Member States through a (subsidiary) branch or agency (art. 58 EC Treaty). ${ }^{148}$ The protection enjoyed as a result of this Community freedom, in the interpretation of the ECJ, overflows also the strict area of discrimination by reason of nationality, constituting a guarantee against all kinds of differences in treatment in the application of any other criteria. ${ }^{149}$ At the same time, it's of great interest to emphasise how the EC Court of Luxembourg has stated that in the circumstance art. 52, first paragraph, second phrase, specifically allows the economic agents the possibility of choosing freely the appropriate legal form for the exercise of their activities in another Member State and this free election should not be limited by discriminatory fiscal arrangements. ${ }^{150}$

In applying this doctrine to Spanish thin capitalisation we can see differences in treatment contrary to the EC freedom of establishment. Imagine for example that this Community freedom would not at first be affected by the Spanish thin capitalisation norm (Law 61/78 and the Project of Corporation Tax Law) when a holding (company group) from a Member State opts to establish itself in Spain through a subsidiary which has residence in Spain. Nevertheless, when this same holding company chooses to introduce itself in Spain through a branch (permanent establishment), the Spanish thin capitalisation norm would be applied in relation to the loans contracted by the same company in favour of Spanish residents and discrimination contrary to the EC right of establishment would occur.

In this last case as well as in the previous one there are direct and indirect differences of fiscal treatment that bring about serious obstacles and restrictions to the effective exercise of the Community freedoms. Even so, the compatibility or incompatibility of these with Community

144 ECJ, 12 April 1994, Case 1/93, ECR, p. I-1137 et seq.

145 See points 19-20 and the decision of the ECJ, 12 April 1994, Case 1/93, ECR, p. I-1137.

146 See also points 31 et seq. of the Bachmann case. Nevertheless, it is important to point out that the Project of New Corporation Income Tax Law avoids this obstacle insofar as it excludes the finance companies from the thin capitalisation law. See para. 1 of art. 20 of the Project (BOF Parliament no. 106-13 A, 6 October 1995).

147 ECJ, 21 June 1974, Reyners, Case 2/74, ECR, p. I-631; 28 April 1977, Thieffry, Case 71/76, ECR, p. I-765; 28 June 1977, R. Hugh Patrick, Case 11/77; 27 September 1988, Daily Mail, Case 81/87, ECR, p. I-5483 (point 15).

${ }^{148}$ In relation to the concept of branch or agency in the sense of arts. 52 and 58 of the Treaty of Rome, see the jurisprudence of the European Court of Justice in the decisions of 24 November 1977, Razanatsimba, Case 65/77, ECR, p. I-2229; 19 January 1988, Güllug, Case 292/86, ECR, p. I-136; 4 December 1986, Commission/Germany, Case 205/84, ECR, p. I-3793; 28 January 1986, Commission/France, Case 270/83, ECR, pp. I-302-303, points 13-15. See also A. Benoit Moury, 'Droit Européén des Sociétés et interpretation des jurisdictions communautaires', Revue de Droit International et de Droit Comparé, 1993/2, pp. 115-116.

149 ECJ, 28 January 1986, Commission/France, Case 270/83, ECR, p. I-285 et seq., especially point 13; 13 July 1993, Commerzbank, Case 1/93, ECR, p. I-4042, points 13-16; 12 March 1994, Halliburton, Case 1/93, ECR, p. I-1556; 11 August 1995, Wielockx, Case 80/94, Semaine de activité de la Cour, no. 22/95, pp. 7-9.

150 ECJ, 28 January 1986, Commission/France, Case 270/83, ECR, p. I-305, point 22; 12 March 1994, Halliburton, Case 1/93, Recp. I-1156, points 19 and 20. 
Law must be judged bearing in mind the other two elements previously mentioned, i.e. the presence of a comparable situation and the existence or non-existence of a cause of justification.

In relation to the existence of a comparable situation, we understand that this analysis must be carried out in a separate way, first, contrasting the position of the resident and non-resident lenders (corporate) in relation to the thin capitalisation norm and, secondly, doing the same between a (corporate) resident lender and a permanent establishment located in Spain that carry out the same operations in the same sector or activity branch.

In relation to the first of these hypotheses, there are many doubts surrounding a positive or negative response. Certainly, the different norm position seems to be centred on the greater possibilities of fiscal evasion or of production of a fiscal (collection) loss that exists when the beneficiary of the interest is a non-resident, in which case it could be understood that the situation is not comparable. However, as it is known that when the lender is a resident of the same country as the borrower the same phenomenon can also be produced, something which can serve to base the existence of a comparable situation. Furthermore, the phenomenon of the globally considered evasion can only be said to take place when the lender resides in a Tax Haven or enjoys a privileged statute, insofar as in the remaining cases the recipient of the interest will be subject to tax in his country of residence supporting a similar fiscal charge to that which exists in the source State. Therefore, in this last case it would not be a fiscal saving, but could be a tax collection loss on the part of borrower's State of residence. In this sense, the existence of the Community mutual assistance instruments and information exchange, as Directive $77 / 799 / \mathrm{EEC}^{151}$ can serve to locate the mentioned case of fiscal evasion, excluding here the existence of a comparable situation and discrimination. Nevertheless, the most reasonable and neutral path for these cases would be to follow the criterion of the EC Court of Justice in the sense of centring the analysis around the existence of a justification for the discrimination. ${ }^{152}$

Also, in relation to the second of the cases to be contrasted, we believe that there exists a reasonably comparable situation to these effects between a (corporate) lender, resident of Spain and a permanent establishment of a Community company located in Spain that carries out these operations in the same economic sector. In effect, following the task of the norm, the situation of a permanent establishment in Spain is equivalent in terms of evasion possibilities and, even, considering the possible tax collection loss for the Spanish Exchequer, than the one which is produced or can be produced when the lender is a resident of Spain. This happens because the benefits that a permanent establishment located in Spain obtains, whether a DTC exists or not, are subject to tax in almost identical form to the corporation who is a resident of Spain in the same activity sector. Therefore, the possibilities of evasion or fiscal loss for the Spanish Public Exchequer is identical in both cases and there is no reason to establish any difference of treatment.

In beginning to analyse the possible justification of the fiscal discriminations that have been previously commented on, it is necessary to carry out a separate examination of the application of the thin capitalisation norm in relation to non-resident corporations, and to consider the case of a permanent establishment (located in Spain) of a non-resident corporation (but Community).

In the first case, knowing that the legitimate objective of the fight against tax evasion or the defence of the national tax income that the norm pursues, the degree of world expansion of this technique and its corollary (the arm's length principle), as well as its acceptance, in given conditions in the framework of the OECD, the difference in treatment that integrates the Spanish norm can be justified. ${ }^{153}$

Nevertheless, it cannot be forgotten that the target justification does not automatically legitimise the means. On the contrary, the execution of this objective must be accompanied by other additional requirements so that the national norm is compatible with EC law. In particular, the ECJ requires that the juridical techniques that execute this target are proportional, indispensable to reach and are established in such a way that the smallest possible obstacle for the Community freedoms originates.

151 EC Journal L.336, p. 15; EE. 09/91, p. 94. This Directive was modified for Directives 79/1070/EEC (EC Journal L.331, p. 8; EE. 09/01, p. 114) and 92/12/EEC (EC Journal L-76, p. 1).

152 See ECJ, 10 July 1986, Segers, Case 79/85, ECR, p. I-2375 (especially points 14-17) and 27 September 1988, Daily Mail, Case 81/87, ECR, p. I-5483.

153 In this point we are not in accordance with the avoir fiscal case, inasmuch as in this decision the possibility that fiscal evasion risks could justify a restriction on the freedom of establishment was excluded (point 25). Nevertheless, I think that one could invoke the Daily Mail and Bachmann decisions to prevent cases of fiscal evasion or tax collection loss on existing tax rights (not future). This interpretation is consistent with and suitable to the resolution of the European Council of the EU of 10 February 1975, in relation to anti-evasion measures (EC Journal of 14 February 1975, no. C 35, pp. 1 and 2; see Intertax, 1975/1, p. 9). See P. Fontaneau, La notion d'evasion fiscal dans la CEE (Tome 1, Les Cahiers fiscaux européennes, Nice, 1978), Chapter III, p. 1 et seq. 
In this sense, we believe that the Spanish anti-thin capitalisation rule approved by Law $61 / 78$, insofar as it fails to prove the suitability of the indebtedness with the arm's length principle, infringes these additional requirements and, therefore, incurs discrimination forbidden by EC law. This incompatibility, would be eliminated introducing the possibility that the taxpayer could prove the existence of a market situation between independent parties, inasmuch as the same objective can be reached (something which shows the dispensable character of that element of the norm) in a way more proportionate and adapted with Community principles. ${ }^{154}$ The thin capitalisation rule established by the Project of Corporation Income Tax Law allows the taxpayer to demonstrate the fulfilment of the arm's length principle. Besides other limitations that were mentioned previously, the Project allows the taxpayer the right of the presence of two requirements. On the one hand, art. 20.4 of this arrangement requires the existence of a DTC with the lender's State of residence. On the other, the Project demands the achievement of the reciprocity condition. These requirements contradict the Treaty of Rome. We believe that the Project now introduces new treatment differences between non-residents with and without DTCs. Certainly, people can argue that Spain has a tax treaty network with the majority of the EU countries (excepting Greece, in process) which makes this discrimination apparent or fictitious. Nevertheless, it must be taken into account that one contracting State could denounce the DTC or deny the reciprocity. In this case the Community taxpayer would suffer discrimination.

The most important facts are that the Community rights and freedoms are imperative and have direct effect, and their application cannot be conditioned to the existence of a national or international rule. In this sense the EC Court declared in the avoir fiscal ${ }^{155}$ case that the rights derived from art. 52 of the Treaty are imperative and a Member State cannot condition the fulfilment of these rights on the existence of a DTC with another Member State. In particular, this article does not allow the requirement of a reciprocity condition for the achievement of these rights. Therefore, the Project of New Corporation Income Tax Law contradicts the Community non-discrimination principle. This infringement could be abolished establishing the unconditional extension of the taxpayer's right to all Community nationals (residents in the EU).

In the second case, i.e. where the Spanish thin capitalisation norm is applied in relation to loans carried out by a permanent establishment in Spain ${ }^{156}$ belonging to a Community corporation non-resident of Spain, the fiscal discrimination is unjustified. The reason for stating this is the consideration that in these hypotheses the possibilities of fiscal evasion or collection loss on existing taxing rights for the Spanish Exchequer is identical when the lender corporation is a resident of Spain. Therefore, there being no different possibilities of tax collection loss or evasion between these two cases, the difference of treatment is arbitrational and poses an unnecessary and groundless obstacle to the freedom of establishment. ${ }^{157}$

In fact, the current Spanish regulation of thin capitalisation (Law 61/78 and the Project of Corporation Income Tax law) is incompatible with EC law (non-discrimination principle). The legal consequence of this Community infringement must be the non-application of the Spanish thin capitalisation to the Community taxpayers protected by this right, ${ }^{158}$ as well as the subsequent eradication of the Spanish legal order of the anti-juridical aspects of this regulation. $^{159}$

154 A good example of the fact that the objective that pursues the thin capitalisation Spanish rule can be reached through more flexible and proportionate means provided by the British thin capitalisation regulation. In this sense, E.C.D. Norfolk, Taxation Treatment of Interest (Butterworths, London, 1992), p. 188, shows the configuration of this arrangement in English Law in the framework of the new s. 808 A introduced in the ICTA 1988 through the $\mathrm{F}\left(\mathrm{n}^{\circ} 2\right)$ to 1992 establishing that:

(a) On the one hand, the consideration of whether the paid interest is excessive takes place 'attending to all the circumstances at stake; these factors should put special emphasis on if, and on what measure of absence in the special relations (lender/borrowing) such loans might have existed, as well as to what type of interest might have been agreed upon in absence of this relation';

(b) On the other hand, 'the new norm also allows the contributor to demonstrate that such special relation does not exist or that the quantity of paid interest might have been satisfied also in absence of this special relation'.

155 EC Court of Justice, 28 January 1986, Case 270/83, ECR, p. I-307, point 26. In the same sense, see EC Court of Justice, 11 August 1995, Wielockx, Case 16/95, points 20, 22 and 27.

156 As we saw previously (see pp. 295-296), the Spanish thin capitalisation norm is contrary to art. 24.3 MC OECD as well.

157 See points 19 and 20 of the decision of 28 January 1986, Commission/France, ECR, pp. I-304-305.

158 Note the non-applicability of the Spanish thin capitalisation rule in relation to the residents of Ireland and Portugal, even when the DTCs establish that the non-discrimination principle does not operate on this matter, because Community Law is high law.

159 See the decision of the ECJ, 15 June 1964, Costa/Enel, Case 6/64, ECR, p. I-1141; 4 April 1974, Commission/France, ECR, p. I-359 et seq.; 17 February 1970, Case 31/69, Commission/Italy, ECR, p. I-25 et seq.; 20 October 1981, Commission/Belgium, ECR, p. I-2393; 15 October 1986, Commission/Italy, ECR, p. I-2945. See also the important and recent leading case of the Superior Court of Justice of Madrid in the decision 450/95, 4 May (JT 1995, Ar. 660) where this court recognises the priority application of the Community law and the European jurisprudence over the Spanish Supreme Court decisions. 
Also, when there is a DTC with the lender's country of residence the Spanish regulation infringes the non-discrimination principle established in most of these treaties. In this way, the rule, when a DTC exists, will be the non-application of the Spanish thin capitalisation norm as well. Only where the agreement does not take up this principle or where the operability of the non-discrimination clause has been avoided will the application of this regulation be allowed.

In this sense, it is surprising that the new norm on thin capitalisation established in the Project of Corporation Tax Law that was sent to Parliament may not have purified these serious defects. To think that the "Report for the Reform of the Corporations Tax Law" "160 of the State Secretariat of the Ministry of Economy and Finance asserted in its day that 'the established norm currently in art. 16.9 of Law 61/78 must be withdrawn and perfected with the object of being able to fulfil perfectly the function that is assigned to it with the most suitable connection with the procedures of the DTCs that has its antecedent in art. 24.5 and 6 (4 and 5 MC OECD 1992) of the Model Agreement of the OECD'.

The most reasonable and convenient results from revising the current thin capitalisation arrangement for the sake of adapting it to the main trends in international taxation (specially, the OECD doctrine) are, to make it compatible with the DTCs and EC law and, especially, to endow it with efficiency and tax justice. Since, as expressed by Professor F. Sáinz Bujanda, ${ }^{161}$ 'above the technique of Law is the Law itself'.

\footnotetext{
161) MEH, Informe para la Reforma del Impuesto sobre Sociedades (MEH, Madrid, 1994), p. 117

161 F. Sainz de Bujanda, Hacienda y Derecho (IEP, Madrid, 1973), vol. IV, p. 197.
} 